\title{
Curcumin Delivery Mediated by Bio-Based Nanoparticles: A Review
}

\author{
Mahshid Moballegh Nasery ${ }^{1,2,3}$, Banafshe Abadi ${ }^{1}$ (D), Delaram Poormoghadam 4 (D), \\ Ali Zarrabi ${ }^{5}$ De , Peyman Keyhanvar ${ }^{6,7}$, Hashem Khanbabaei ${ }^{8}$ (D), Milad Ashrafizadeh ${ }^{9}$ (D),
} Reza Mohammadinejad 10,*, Shima Tavakol ${ }^{11, *}$ and Gautam Sethi ${ }^{12, *}$

1 Student Research Committee, Kerman University of Medical Sciences, Kerman 7619813159, Iran; nasery278@gmail.com (M.M.N.); banafshe.abadi@yahoo.com (B.A.)

2 Department of Toxicology \& Pharmacology, School of Pharmacy, Kerman University of Medical Sciences, Kerman 7616911319, Iran

3 Nanomedicine Research Association (NRA), Universal Scientific Education and Research Network (USERN), Tehran 7616911319, Iran

4 Department of Medical Nanotechnology, Faculty of Advanced Sciences \& Technology, Pharmaceutical Sciences Branch, Islamic Azad University, (IAUPS), Tehran 1916893813, Iran; parand.pdrm@yahoo.com

5 Sabanci University Nanotechnology Research and Application Center (SUNUM), Tuzla, Istanbul 34956, Turkey; alizarrabi@sabanciuniv.edu

6 Research Center for Pharmaceutical Nanotechnology, Faculty of Pharmacy, Tabriz University of Medical Sciences, Tabriz 5165665811, Iran; regenerative.md@gmail.com

7 Department of Medical Nanotechnology, School of Advanced Medical Sciences, Tabriz University of Medical Sciences, Tabriz 5165665811, Iran

8 Medical Physics Department, School of Medicine, Ahvaz Jundishapur University of Medical Sciences, Ahvaz 6135715794, Iran; khanbabaie.mph@gmail.com

9 Department of Basic Science, Faculty of Veterinary Medicine, University of Tabriz, Tabriz 5166616471, Iran; dvm.milad73@yahoo.com

10 Neuroscience Research Center, Institute of Neuropharmacology, Kerman University of Medical Sciences, Kerman 7616911319, Iran

11 Cellular and Molecular Research Center, Iran University of Medical Sciences, Tehran 1449614525, Iran

12 Department of Pharmacology, Yong Loo Lin School of Medicine, National University of Singapore, Singapore 117600, Singapore

* Correspondence: r.mohammadinejad@kmu.ac.ir (R.M.); tavakol.sh@iums.ac.ir (S.T.); phcgs@nus.edu.sg (G.S.)

Received: 26 December 2019; Accepted: 2 February 2020; Published: 6 February 2020

\begin{abstract}
Todays, nano-pharmaceutics is emerging as an important field of science to develop and improve efficacy of different drugs. Although nutraceuticals are currently being utilized in the prevention and treatment of various chronic diseases such as cancers, a number of them have displayed issues associated with their solubility, bioavailability, and bio-degradability. In the present review, we focus on curcumin, an important and widely used polyphenol, with diverse pharmacological activities such as anti-inflammatory, anti-carcinogenic, anti-viral, etc. Notwithstanding, it also exhibits poor solubility and bioavailability that may compromise its clinical application to a great extent. Therefore, the manipulation and encapsulation of curcumin into a nanocarrier formulation can overcome these major drawbacks and potentially may lead to a far superior therapeutic efficacy. Among different types of nanocarriers, biological and biopolymer carriers have attracted a significant attention due to their pleiotropic features. Thus, in the present review, the potential protective and therapeutic applications of curcumin, as well as different types of bio-nanocarriers, which can be used to deliver curcumin effectively to the different target sites will be discussed.
\end{abstract}

Keywords: curcumin; cancer; nanocarriers; biopolymer; exosomes 


\section{Introduction}

In ancient cultures, the plants played a crucial role in providing food, spices, and medication to the human population [1-4]. A number of nutraceuticals have displayed significant health benefits, in modern era among which curcumin has been extensively studied for its pleiotropic therapeutic actions [5]. The rhizome turmeric derived from Curcuma longa Linn consists of various curcuminoids, including curcumin, demethoxycurcumin and bisdemethoxycurcumin [6,7]. Among these curcuminoids, curcumin is the most abundant polyphenolic compound in turmeric, which is widely used as a spice and flavoring agent in the food [8]. It was discovered about two centuries ago and has a slightly bitter taste, peppery flavor, and smell like mustard with yellow color [8]. Pharmacologically, curcumin is safe and can mitigate tumor initiation as well as metastasis in breast, colon, pancreatic, oral and several other cancers [9-12]. As mentioned earlier, curcumin has shown remarkable anticancer activities by affecting diverse molecular targets. It can lead to an increased expression of Bax and p53 (pro-apoptotic proteins), suppression of vascular endothelial growth factor (VEGF) and hypoxia-inducible factor 1-alpha [HIF-1 $\alpha$ ] (angiogenesis factors), reduction of the pro-inflammatory responses, induction of autophagy and improvement of drug efflux in drug resistance cancer cells [13-17]. It also appears to be a promising agent for the treatment of brain disorders, cholesterol, and endothelial dysfunctions and can serve as a potent anti-inflammatory and anti-viral agent as well [18]. Furthermore, there is a report on the reduction of opioid tolerance by curcumin through the inhibition of the activity of $\mathrm{Ca} 2+/$ calmodulin-dependent protein kinase II $\alpha$. This kinase has been found to be critical for the opioid tolerance [19]. Notably, curcumin at an optimized dose has low toxicity and is inexpensive, which makes it an ideal herbal for clinical applications [20]. Notwithstanding, the poor bioavailability of curcumin may limit its application in clinical administrations [21]. However, the low concentrations of curcumin are sufficient for its biological activity and they may apply as a supplement in multiple targets therapy in combination with other medications to improve their therapy efficacy [22]. To date, several curcumin carriers have been synthesized as a drug delivery system using viruses, liposomes, magnetic nanoparticles (NPs), ultrasound microbubbles, etc. $[23,24]$. It is important to mention that the size of nanocarriers may also affect the therapeutics effect of their cargo [25]; for example, Tavakol et al. showed that the size of a carrier changes the therapeutic effect and biocompatibility of curcumin [26]. Moreover, the chemical and physical nature of carriers may induce side effects, including organ toxicity and/or immune responses $[27,28]$. Moreover, carriers may exhibit non-uniform particle size distribution, particle agglomeration, non-specific uptake, and rapid clearance from the blood [28-30]. Liposomes are one of the most popular carriers used in drug delivery [31-33]; however, in some cases, they suffer from fast elimination from the blood circulation, physical and chemical instability, aggregation, fusion, degradation, hydrolysis and phospholipid oxidation [29,34].

Recently, different types of biopolymers have been introduced with the capability of being used as carriers for delivering curcumin among them are chitosan, starch, zein, alginate, silk, etc. The distinguishing features of these nano-systems like biodegradability, biocompatibility, eco-friendliness, and a wide range of commercial applications have made them as an ideal candidates for the drug delivery applications [35]. These types of polymers can incorporate drugs through two main methods; desolvation process (for proteins) and nanoprecipitation (for polysaccharides) in different forms of the hydrogels, single biopolymers, and complex biopolymers [36].

The other types of nanocarriers are biological carriers like exosomes that are secreted by most cells of the body and provide a favorable drug delivery efficacy [30]. Exosome diameter is in the range of $30-120 \mathrm{~nm}$, and they can be derived from the extracellular fluids such as blood, urine, amniotic fluid, saliva, and cerebrospinal fluid. Exosomes can carry many molecules like RNA, proteins, and lipids [37]. Interestingly, encapsulation of curcumin into the exosome can improve curcumin solubility, stability, and it's in vitro and in vivo bioavailability [38]. As mentioned earlier, the therapeutic efficacy of curcumin generally requires low to moderate concentrations, which are attainable by encapsulation of curcumin into exosomes. Curcumin-encapsulated exosomes provide 
high plasma concentration along with low toxicity and immune response induction [18]. In addition to their anti-aging and antioxidant properties, they can be effective against venom activities, protozoal and microbial contamination, inflammatory responses, angiogenesis procedure, and tumor suppression through the presence of exosomes [39]. The present review is a short description of curcumin, a widely used polyphenol exhibiting anti-cancer and anti-inflammatory activities and different biopolymeric as well as biological nanocarriers that can be used to facilitate substantial improvement in its bioavailability for therapeutic applications.

\section{Application of Curcumin for Cancer Therapy}

Cancer is regarded as a major global public health problem [40-42]. The rate of cancer mortality is increasing worldwide from 2012 to 2015. In 2012, cancer caused 8.2 million deaths that rose to 8.8 million deaths in 2015. Notably, it is predicted that global cancer causes will be over 20 million new cases by 2025 [43]. There are different types of therapeutic options for cancer therapy including radiotherapy, immunotherapy, surgery, chemotherapy, etc., among them, chemotherapy is known as the most abundant method used for global cancer treatment [44,45]. Interestingly, SarinaMedTrip a famous international health tourism company utilizes the latest technologies in the world to treat cancer patients [46]. However, the chemical drugs used for chemotherapy exhibit several side effects such as nausea, vomiting, hair loss, leukopenia, diarrhea, hepatotoxicity, nephrotoxicity, etc.

Recently, natural agents have received lots of attention due to their diverse pharmacological activities [47-52]. They are derived from plants with the ability of cancer prevention or treatment possibly with reduced side effects [53-61]. Curcumin can exhibit a wide range of pharmacological potential [62-64] including anti-inflammatory, anti-oxidant, anti-proliferative, chemo-sensitizing, cell cycle arrest, and can display apoptotic potential against various cancer cells, such as colorectal, breast, pancreatic, and colon cancers [65] that makes it of great interest in cancer prevention and therapy [66,67]. Notably, IC50 of curcumin in healthy cells is significantly higher than cancer cells [68]. In other words, it is well tolerated and used as a spice, coloring agent, and supplement up to a dose of 12 gram/day [69].

Notwithstanding, it is not entirely understood how curcumin is responsible for cell protection [68]. For example, the anti-inflammatory potential of curcumin plays a critical role in cancer therapy [70]. Moreover, curcumin inhibits the activity of transcription factor NF- $\kappa$ B and prevents its transmission to the nucleus. Therefore, it can lead to the down-regulation of various inflammatory and oncogenic genes [6]. Besides its anti-inflammatory potential, there are some reports on the dual role of curcumin as a reactive oxygen radical scavenger and producer; however, it appears that curcumin through the reactive oxygen radical production can also induce apoptosis in cancer cells [68]. It is noteworthy, that curcumin can also affect multiple cell signaling pathways to negatively affect cancer cells, for example, it inhibits VEGF and suppresses VEGF receptor-2, fibroblast growth factor 2, matrix metalloproteinases, 2 and 9 etc [66].

Curcumin has shown its positive effects both in vivo and in vitro models [71,72]. It has anti-proliferative potential in a concentration-dependent manner [70] and is useful in combination with anticancer agents; for example, its cytotoxicity in prostate cancer cells reduces the survival of these cells [69]. It also affects cancer stem cells and shows anti-metastatic activity [43] and can be well tolerated at doses near $8000 \mathrm{mg} /$ day [73]. In one report, the effect of orally consumed curcumin on the apoptosis of colon tumors was investigated. Their results indicated that curcumin, as a nutritional supplement can enhance apoptosis and inhibit tumor progression [74]. Based on another study, it was concluded that curcumin can also mitigate the progression of hepatoma cells and metastases, which are driven by EMT-induced through TGF- $\beta 1$. The authors suggested that curcumin suppresses the phosphorylation of Smad 2 through the TGF- $\beta 1$ over-expression that resulted in Snail down-regulation [70]. 


\section{Challenges Associated with Curcumin Delivery}

Although a large number of nutraceuticals have shown substantial anti-cancer potential by inhibiting various oncogenic molecular pathways in cancer cells and preclinical studies, they have failed in clinical trials owning to their low bioavailability $[32,33,75,76]$. However, curcumin has shown significant benefits in clinical settings and it has been found to be non-toxic and fairly well-tolerated, however its solubility, and bioavailability may limit its usage in patients [7]. In other words, clinical use of curcumin in the patients may be limited due to its low bioavailability, short half-life in plasma, low solubility in water, and low stability $[8,41,75,77]$ and it may necessitate high dose intake to achieve optimal therapeutic effects. Interestingly, several of the important anti-carcinogenesis effects of curcumin may be related to its significant ability to modulate transcription factor NF- $\mathrm{kB}$ activation, however, it suffers from poor bioavailability and solubility. To overcome this obstacle, Elias et al. prepared curcumin in guar gum tablet and enhanced curcumin solubility and bioavailability effectively [78].

The second problem associated with its application is its rapid metabolism and enterohepatic circulation that necessitates the higher doses of curcumin to induce pronounced efficacy $[41,69]$. Moreover, fast clearance from the bloodstream through the phagocytosis and reticuloendothelial system is another major issue [75]. There are many investigations related to the enhancement of solubility and stability of curcumin, for example, encapsulation of curcumin into lipid based carriers, conjugation with nanoparticles, etc [26,41]. In the rest of the review, we have discussed these diverse methods and highlighted the various procedures to overcome these drawbacks and increase curcumin efficacy in the patients.

\section{Biopolymer Nanoparticles (NPs)}

Biopolymeric particles are colloidal structures that are assembled from one and multiple types of biopolymer molecules and can be utilized as carriers for bioactive compounds [79-82]. Biopolymeric particles can be used to improve the stability of bioactive molecules from the bio-degradation, enhance their absorption, and deliver them to the target sites [83]. Notwithstanding, they can act as a controlled release system for the sustained and controlled release of their ingredients [84]. Biopolymeric particles are classified based on the method of preparation (inclusion complex), types of nano dimensions (nanofiber, nanosphere, etc.) [85-87] and chemical components (chitosan, gelatin, etc.) [88-90]. As shown in Table 1, there are several investigations address the methods of nanocurcumin preparation and its biological efficacy (in vitro and in vivo). 
Table 1. A list of different curcumin nanocarriers with their characteristics and applications under in vitro and in vivo settings.

\begin{tabular}{|c|c|c|c|c|c|c|}
\hline Polymer & Size & Zeta Potential & LC or EE & $\begin{array}{l}\text { Cell Line/Animal } \\
\text { Model }\end{array}$ & Advantages & Refs. \\
\hline BSA@CUR NPs & $92.59 \pm 16.75 \mathrm{~nm}$ & $-9.19 \mathrm{mV}$ & $18.3 \%$ & MCF-7 cells & Increased therapeutic efficacy & [77] \\
\hline $\begin{array}{l}\text { Curcumin in } \\
\text { BSA-dextran NP }\end{array}$ & $115 \mathrm{~nm}$ & & $2.8 \%$ & Caco- 2 cells & $\begin{array}{c}\text { Better stability } \\
\text { Improve the cellular antioxidant activity of } \\
\text { curcumin }\end{array}$ & [91] \\
\hline $\begin{array}{c}\text { Curcumin } \\
\text { cross-linked HSA NPs }\end{array}$ & $125 \mathrm{~nm}$ & $\begin{array}{l}-12.36 \pm 0.73 \text { to } \\
-10.88 \pm 0.6 \mathrm{mV}\end{array}$ & $\begin{array}{l}\text { was dependent on the } \\
\text { particle size }\end{array}$ & A549 cells & $\begin{array}{l}\text { Improved cellular uptake } \\
\text { Increased the cytotoxicity }\end{array}$ & [92] \\
\hline $\begin{array}{l}\text { Curcumin-loaded } \\
\text { zein NPs }\end{array}$ & $66 \mathrm{~nm}$ & $+17.1 \mathrm{mV}$ & $7.3 \pm 0.1 \%$ & GIT model & $\begin{array}{l}\text { May be useful for application in functional } \\
\text { foods or beverages }\end{array}$ & [93] \\
\hline $\begin{array}{l}\text { Curcumin-zein/rhamnolipid } \\
\text { complex }\end{array}$ & $77.29 \mathrm{~nm}$ & $-31 \mathrm{mV}$ To $+3 \mathrm{mV}$ & EE: $98.05 \%$ & $\begin{array}{l}\text { In vitro simulated } \\
\text { gastrointestinal tract }\end{array}$ & Protect hydrophobic bioactive compounds & [94] \\
\hline Pectin-coated CZ NPs & $250 \mathrm{~nm}$ to $600 \mathrm{~nm}$ & -45 to $-50 \mathrm{mV}$ & $5 \%$ & $\begin{array}{l}\text { Simulated } \\
\text { gastrointestinal } \\
\text { digestive condition }\end{array}$ & $\begin{array}{l}\text { Enhanced antioxidant activity } \\
\text { in an aqueous environment }\end{array}$ & [95] \\
\hline $\begin{array}{l}\text { Curcumin-loaded } \\
\text { zein NPs with (SC) } \\
\text { and (SA) }\end{array}$ & $190 \mathrm{~nm}$ & $17 \mathrm{mV}$ to $19.8 \mathrm{mV}$ & EE: $36.10 \%$ to $76.06 \%$ & & $\begin{array}{l}\text { Improving the water solubility } \\
\text { Improving photochemical stability improving } \\
\text { antioxidant activity }\end{array}$ & [96] \\
\hline $\begin{array}{l}\text { Curcumin-loaded silk } \\
\text { fibroin NPs }\end{array}$ & $155 \mathrm{~nm}$ to $170 \mathrm{~nm}$ & $-45 \mathrm{mV}$ & EE: $50 \%$ & Kelly Cells & Higher efficacy in cytotoxicity & [7] \\
\hline Curcumin plus SFNs & $71 \pm 10 \mathrm{~nm}$ & & $\begin{array}{l}1.50 \pm 0.11 \text { to } 11.40 \pm \\
0.76\end{array}$ & $\begin{array}{l}\text { In vitro model of } \\
\text { osteoarthritis }\end{array}$ & $\begin{array}{l}\text { Exhibited a synergistic antioxidant effect } \\
\text { Improve cyto- and hemo-compatibility }\end{array}$ & [97] \\
\hline CUR-loaded silk NPs & $229 \mathrm{~nm}$ to $2286 \mathrm{~nm}$ & $-17.8 \mathrm{~nm}$ to $-18.9 \mathrm{mV}$ & 22 to $41 \%$ & Rats & Longer plasma circulation time & [98] \\
\hline $\begin{array}{l}\text { CUR Loaded } \\
\text { RBA-CS NPs }\end{array}$ & $778 \mathrm{~nm}$ & Negative & EE: $93.56 \%$ & Caco- 2 cells & $\begin{array}{l}\text { A great potential application for hydrophobic } \\
\text { active agent delivery }\end{array}$ & [99] \\
\hline Zein-HA NPs & $186.4 \mathrm{~nm}$ & -35.2 to $-28.7 \mathrm{mV}$ & $3.66 \%$ & $\begin{array}{l}\text { Simulate } \\
\text { gastrointestinal } \\
\text { digestion }\end{array}$ & $\begin{array}{l}\text { Better stability of anti-light degradation, } \\
\text { and control release }\end{array}$ & [100] \\
\hline SSPS NPs & $200 \mathrm{~nm}$ to $300 \mathrm{~nm}$ & & EE: $90 \%$ & $\begin{array}{l}\text { HCT116 and MCF-7 } \\
\text { cells }\end{array}$ & $\begin{array}{l}\text { Improved activity } \\
\text { Improvement in the anti-proliferative activity }\end{array}$ & [101] \\
\hline Cur-ACRU/CS NPs & $200 \mathrm{~nm}$ to $450 \mathrm{~nm}$ & $+15 \mathrm{mV}$ & $5.4 \%$ & Caco-2 cells & $\begin{array}{l}\text { Improved permeability efficiency } \\
\text { of free curcumin }\end{array}$ & [102] \\
\hline
\end{tabular}


Table 1. Cont.

\begin{tabular}{|c|c|c|c|c|c|c|}
\hline Polymer & Size & Zeta Potential & LC or EE & $\begin{array}{l}\text { Cell Line/Animal } \\
\text { Model }\end{array}$ & Advantages & Refs. \\
\hline Cur-Chitosan NPs & $167 \mathrm{~nm}$ to $251 \mathrm{~nm}$ & +18.1 to $+20.2 \mathrm{mV}$ & EE: $80 \%$ & $\mathrm{HaCaT}$ cells & $\begin{array}{c}\text { Superior drug release } \\
\text { Enhanced transdermal permeation of curcumin } \\
\text { A superior percentage of cell viability }\end{array}$ & [103] \\
\hline CDG-CANPs & $215 \mathrm{~nm}$ & $-24.1 \mathrm{mV}$ & $27 \%$ & Caco- 2 cells & $\begin{array}{l}\text { Improvement of physicochemical stabilities, } \\
\text { digestibility, bioaccessibility and cellular uptake }\end{array}$ & [104] \\
\hline CUR-AlgNP & $100-600 \mathrm{~nm}$ & $-36.0 \pm 0.4$ & EE: $68.3 \%$ & HeLa and H9c2 & Kills the cancer cell lines at lower concentrations & [105] \\
\hline Cur-CS/Alg NPs & $199 \mathrm{~nm}$ to $1120 \mathrm{~nm}$ & $-30.8 \mathrm{mV}$ to $-10.8 \mathrm{mV}$ & $0 \%$ to $27.4 \%$ & HaCaT cells & Improved the cellular uptake of curcumin & [106] \\
\hline Starch NPs & $<250 \mathrm{~nm}$ & $-30 \mathrm{mV}$ & EE: $80 \%$ & $\begin{array}{l}\text { Simulated gastric and } \\
\text { intestinal fluids }\end{array}$ & Higher encapsulation efficiency & [107] \\
\hline $\begin{array}{l}\text { OSA starch loaded } \\
\text { nano curcumin }\end{array}$ & $10 \mathrm{~nm}$ to $50 \mathrm{~nm}$ & & & HeLa cells & $\begin{array}{c}\text { Anti-cancer potential } \\
\text { Significant enhancement in cellular uptake } \\
\text { Increase bioavailability } \\
\text { More controlled release }\end{array}$ & [108] \\
\hline Curcumin-load film & $\begin{array}{l}159 \pm 31 \mathrm{~nm} \text { in length } \\
\text { and } 2 \mathrm{~nm} \text { in width. }\end{array}$ & & & Rat & $\begin{array}{l}\text { Improved the regeneration of hair follicles } \\
\text { And sebaceous glands of the skin } \\
\text { Attenuated the bacterial growth }\end{array}$ & [109] \\
\hline Cur- NLCs & $500 \mathrm{~nm}$ & & $\mathrm{EE} \sim 58.8 \pm 3.5$ & Mouse & $\begin{array}{l}\text { Reducing the pro-inflammatory cytokine levels } \\
\text { in the skin }\end{array}$ & [110] \\
\hline ANC NPs & $\leq 150 \mathrm{~nm}$ & $-31.2 \pm 3.66 \mathrm{mV}$ & $\mathrm{EE}>90 \%$ & L929 and MCF-7 cells & $\begin{array}{l}\text { Inhibit microbial growth } \\
\text { Prevent preferential killing of cancer cells } \\
\text { compared to normal cells }\end{array}$ & [111] \\
\hline WPI-Lac/EGCG NPs & $110 \mathrm{~nm}$ & $27 \mathrm{mV}$ & & & $\begin{array}{l}\text { Better protective effect on the breakdown of } \\
\text { curcumin in Pickering emulsions } \\
\text { More even droplet distribution } \\
\text { Greater thermal stability } \\
\text { Higher curcumin percentage retention }\end{array}$ & [112] \\
\hline $\begin{array}{c}\text { CUR-Loaded } \\
\text { Gel-mPEG Nanogels }\end{array}$ & $147 \pm 5.2 \mathrm{~nm}$ & $-12.8 \pm 0.6$ & $7.9 \pm 0.2 \%$ & HeLa cells & $\begin{array}{c}\text { Improved solubility } \\
\text { Enhanced therapeutic efficacy }\end{array}$ & [113] \\
\hline
\end{tabular}


Table 1. Cont.

\begin{tabular}{|c|c|c|c|c|c|c|}
\hline Polymer & Size & Zeta Potential & LC or EE & $\begin{array}{l}\text { Cell Line/Animal } \\
\text { Model }\end{array}$ & Advantages & Refs. \\
\hline $\begin{array}{l}\text { Curcumin-loaded } \\
\text { BSA NPs }\end{array}$ & $150 \mathrm{~nm}$ & Negative & EE: $45 \%$ & $\begin{array}{c}\text { Murine } \\
\text { melanoma model }\end{array}$ & $\begin{array}{l}\text { Increase in survival rate associated with a } \\
\text { reduction in tumor size }\end{array}$ & [114] \\
\hline $\begin{array}{c}\text { Curcumin } \\
\text { loading EWP }\end{array}$ & $59.25 \mathrm{~nm}$ to $431.3 \mathrm{~nm}$ & $>+30 \mathrm{mV}$ & $11.2 \mathrm{mg} / \mathrm{g}$ & & $\begin{array}{l}\text { Protect the antioxidant activity } \\
\text { of encapsulated curcumin }\end{array}$ & [115] \\
\hline Curcumin-PECs & $264.0 \pm 3.1 \mathrm{~nm}$ & & EE: $53 \%$ & HCT116 cells & $\begin{array}{l}\text { Induced cell cycle arrest } \\
\text { Exhibited cytotoxic effect }\end{array}$ & [116] \\
\hline
\end{tabular}




\subsection{Protein-Based Biopolymers}

\subsubsection{Albumin}

Albumin is one of the main proteins of plasma with high stability, biodegradability, non-immunogenicity, and biocompatibility. Moreover, it has lots of binding sites in its matrix that make it an ideal platform for drug loading [77]. Human serum albumin (HSA) is one of the smallest proteins in blood plasma, which can transport therapeutics in the bloodstream. Furthermore, albumin-binding proteins are over-expressed on the surface of endothelial cells in tumor vessels, and therefore, HSA can be accumulated in the tumor sites through transcytosis across continuous endothelium $[117,118]$. Since the low water solubility of curcumin and its poor bioavailability may result in the decrease of therapeutic efficacy, encapsulation of curcumin into a water-soluble albumin carrier can be useful to overcome these obstacles [119]. For instance, in a recent study, curcumin was encapsulated into the HSA particles to achieve a redox-responsive release of curcumin. According to the results, the release of curcumin was considerably increased in the presence of glutathione in the physiological $\mathrm{pH}$ (7.4) of the body or acidic $\mathrm{pH}$ (5.5) of the tumor environment during the $48 \mathrm{~h}$ (57\% and $70 \%$ of the loaded drugs, respectively). Moreover, HSA particles improve cellular uptake of curcumin compared to free curcumin that leads to increase anti-cancer efficacy [77]. In another study, curcumin was encapsulated into the bovine serum albumin (BSA)-conjugated dextran NP resulting in increasing the size from $<200 \mathrm{~nm}$ to $512 \mathrm{~nm}$. Notably, NPs showed high stability against pH and temperature changes with high cellular antioxidant activity [91]. Moreover, Saleh et al. deciphered the potential of human epidermal growth factor receptor 2 (HER2) aptamer-decorated human serum albumin NPs loaded with curcumin $(281 \mathrm{~nm})$ on HER2 overexpressing breast cancer cells. They showed that curcumin conjugated Apt-HSA/CCM NPs significantly augmented aqueous solubility and cellular uptake. Cytotoxicity was also elevated crucially on the SK-BR3 cell line compared with unconjugated counterparts [120]. The optimal size of NPs is fundamental to achieving the maximum cellular uptake. A more recent examination with curcumin cross-linked HSA NPs in a size range of 25-250 nm conducted by Das et al. showed that $125 \mathrm{~nm}$ particles found to have noticeable cellular uptake and cytotoxicity on A549 cell line compared to the free drug [92].

\subsubsection{Zein-Based NP}

Zein is an alcohol-soluble protein that is the major protein in the corn kernels and is made up of a high level of non-polar amino acid. This feature along with other properties like high biocompatibility and stability makes it an ideal polymeric carrier for encapsulation of hydrophobic molecules like curcumin [121,122]. The zein-hyaluronan NPs loaded with curcumin were prepared by the anti-solvent co-precipitation method. Results indicated in curcumin loaded into these carriers showed high stability against light and resulting in a controlled release system in simulated gastrointestinal digestion [100]. Therefore, zein NPs can be used to encapsulate curcumin and enhance curcumin efficiency [123,124].

Zein can also be used in combination with other types of reagents, for example, electrostatic complexes consisting of a protein (gelatin) and a polysaccharide (alginate) were prepared to coat and stabilize zein NPs loaded with curcumin [93]. Moreover, hyaluronan was also used as a coating agent to achieve high encapsulation efficiency, loading capacity, greater stability, and controlled release system during gastrointestinal digestion [100]. Moreover, the potential of a zein-caseinate composite as a carrier has also been investigated. The results showed high re-dispersibility in water, high encapsulation efficiency, bioavailability and anti-oxidant property of curcumin [94]. Furthermore, to improve the stability of these NPs, pectin was used as a carbohydrate-based coating. Pectin coating not only increased the loading capacity of NPs to encapsulate curcumin but also promoted a sustained release of curcumin under gastrointestinal conditions [95].

Chen et al. synthesized a combination therapy system of a layer-by-layer NPs consisting of curcumin entrapped into Zein NPs. The NPs were covered by a quercetagetin shed and hyaluronic acid (HA). The size of particles was $231 \mathrm{~nm}$ and showed convincing physical stability and slow rate 
release as well as a decreased light and thermal degradation [122]. In another study, curcumin was loaded into Zein NPs and then they were double coated with sodium caseinate and sodium alginate to stabilize the NPs structure $(\sim 70 \mathrm{~nm})$. Aqueous solubility, drug-controlled release, photochemical stability, and antioxidant scavenging activities were promoted significantly as compared to the unbound curcumin. Much of recent literature on loading curcumin into nanoscale carriers are perpetrating intended for the goal of improved oral drug delivery to the gastrointestinal tract [96]. Zein also was used in the form of nanogel which was cross-linked with HA, as targeting agent, for curcumin delivery, that showed improvement in the in vitro and in vivo pharmaceutical activity of the drug [125]. In another study, zein and l-carrageenan were used as core-shell NPs to prepare a photo and thermal stable carrier for co-delivery of curcumin and piperine [126].

\subsubsection{Silk-Based NPs}

Silk fibroin is a type of biopolymers with different secondary structures ( $\alpha$-helix, $\beta$-sheets, coil, etc), which are used in different constructions like film, hydrogel, matrix, fiber, NPs, etc. [127]. It seems that due to remarkable properties such as high stability, negatively charged, and low toxicity, silk NPs attract much attention to be used as a carrier for curcumin. Notably, the curcumin-loaded silk fibroin NPs showed considerable cytotoxicity against neuroblastoma cells [7]. In another study, curcumin was loaded into magnetic silk fibroin core-shell NPs as an external magnet for cancer targeting. The composite showed high cytotoxicity and cellular uptake against triple negative breast cancer MDA-MB-231 cells [128]. Crivelli et al. revealed that curcumin encapsulated into silk fibroin NPs $(71 \pm 10 \mathrm{~nm})$ enhances in vitro antioxidant, anti-inflammatory activities, and cell viability. The remarkable anti-inflammatory properties of curcumin have been established as a promising strategy for osteoarthritis treatment [97].

In a recent experiment, oral administration of curcumin- loaded silk particles with a wide size range of 229-2286 $\mathrm{nm}$ carried out for evaluating the correlation between particle size and bioavailability in rat models. Larger silk particles (with a size of about $800 \mathrm{~nm}$ ) exhibited longer plasma half-life and slower release rate, while smaller silk particles (with a size of about $200 \mathrm{~nm}$ ) indicated higher bioavailability and Cmax. Bioavailability was 5-fold and 17-fold higher than free drug in 800 and $200 \mathrm{~nm}$ particles, respectively [98]. In another study, a silk nanofiber membrane is produced to co-load curcumin and 5-fluorouracil. The prepared membrane had about 100-200 nm size that released its cargo during a steady and consisted method and thus, it can use as an ideal anti-cancer delivery system [129].

\subsubsection{Other Protein-Based NPs}

Different proteins with various sources have been used as a carrier for curcumin [130-132]. For instance, in 2019, Radix Pseudostellariae protein (RPP)-based NPs were fabricated to loaded with curcumin. The curcumin-loaded nanocomplexes with a size of $100 \mathrm{~nm}$ showed considerable thermal stability and high light stability [133]. In another study, proso millet protein was utilized as a carrier to increase curcumin therapeutic efficacy. The millet-curcumin has a spherical shape with $300 \pm 50 \mathrm{~nm}$ size and an extensive range of drug loading, which was attributed to the millet extraction method [134].

Rice bran waste is rich in proteins and other essential compounds such as lipids, vitamins, and trace minerals. In a recent study, the rice bran albumin (RBA) was derived from the rice bran waste to be used as a carrier for curcumin. RBA was blended with chitosan and formed NPs through the self-assembly method. The results showed RBA-chitosan NPs improves the solubility and high entrapment efficiency of curcumin (about $93.56 \%$ ). The RBA-chitosan NPs showed low bio-degradability in gastric conditions along with satisfied biodegradability and high cytotoxicity against cancerous cells compared to free curcumin that confirmed its usefulness as a drug delivery carrier [99]. Recently, a dual triggerable release nanosystem was prepared to encapsulate curcumin. In this study, novel hydrogel NPs based on fibrous structural proteins (keratin) and thermo-responsive copolymers (Pluronic) have been fabricated to achieve redox and temperature-responsive release of curcumin, and the results were promising. 
In fact, by changing the temperature from $25^{\circ} \mathrm{C}$ to $37^{\circ} \mathrm{C}$, the size of the drug-loaded nanocarrier was also reduced from $165 \mathrm{~nm}$ to $66 \mathrm{~nm}$ that revealed the drug release property of the nano-system due to its thermo-responsive property [135]. Moreover, Li et al. loaded curcumin into solid and hollow Kafirin (a protein found in sorghum grain) and then coated with layer by layer deposition of Dextran sulfate/Chitosan. Particle sizes were around $\sim 60$ and $\sim 125 \mathrm{~nm}$ for hollow and solid NPs, respectively. Despite their smaller size, hollow NPs presented greater encapsulation efficiency. The release rate in both hollow and solid structures was higher than free curcumin, while hollow NPs manifested lower release compared to solid ones [136].

\subsection{Polysaccharide NPs}

Polysaccharides are composed of repeated monosaccharide units joined bound by glycosidic bonds. Due to their advantages, such as high stability, biocompatibility, and biodegradability, they can be used for different applications in biomedical field [95].

\subsubsection{Chitosan}

One of the most commonly used polysaccharides for the preparation of nanocarriers is chitosan [137]. Chitosan is a linear cationic heteropolymer derived by the partial deacetylation of natural chitin. It was introduced by Charles Rouget in 1859 for the first time and can promote cell membrane permeability, and thus, enhance absorption across intestinal epithelia $[138,139]$. It is a positively charged polymer with D-glucosamine and $N$-acetyl-D-glucosamine units and excellent properties like biocompatibility, biodegradability, low immunogenicity, and antibacterial activity that make it an ideal carrier for drug delivery purposes [140,141].

It is widely used as a carrier for delivering curcumin, alone or in combination with different types of components, for example: the polyelectrolyte complexation of positively charged chitosan and negatively charged acylated cruciferin, was used for the curcumin entrapment. In vitro control-release studies showed the controlled release of curcumin using simulated gastro-intestinal fluids; however, the curcumin NPs showed non-toxicity against Caco-2 cells [102]. Curcumin- loaded chitosan NPs (167-251 nm) exhibited enhanced entrapment efficiency, enhanced transdermal permeation, improved drug release, and high cell viability in transdermal drug delivery [103].

In a recent study, curcumin loaded chitosan NPs with a size of about $200 \mathrm{~nm}$ were prepared to be used as a chemotherapeutic agent for lung cancer. The results of this research confirmed a significant improvement in the cytotoxicity of the drug-loaded nanocarrier and also introduced this type of nanosystem as an oral supplement against environmental carcinogenesis [142]. In another study, curcumin was loaded into a pH-responsive nanocapsule that is composed of mesoporous silica and chitosan for using against the U87MG glioblastoma cancer cell line. The nanocarriers had about $88.1 \pm 4.76 \%$ encapsulation efficiency and curcumin release was sustained-in acidic $\mathrm{pH}(\sim 42.72 \%$ during $96 \mathrm{~h}$ ). Moreover, this form of curcumin encapsulation could reduce the IC50 of it from $15.2 \mu \mathrm{g} / \mathrm{mL}$ for the free drug to $5.21 \mu \mathrm{g} / \mathrm{mL}$ for the loaded one [143]. Razi et al. prepared a formulation of genipin cross-linked caseinate chitosan NPs for curcumin delivery, that had about $250 \mathrm{~nm}$ size and could increase the stability and anti-cancer property of the curcumin [144].

\subsubsection{Alginate}

Alginate is a negatively charged biodegradable polysaccharide, which is composed of 1-4 linked $\alpha$-L-guluronic $(\mathrm{G})$ and $\beta$-D-mannuronic $(\mathrm{M})$ acid residues and can exclude from gulfweed, bacteria or seaweed of brown algae [145]. It is a linear polysaccharide that has significant advantages like high mucoadhesiveness, aqueous solubility, biodegradability, $\mathrm{pH}$ sensitivity, and biocompatibility [146]. Sorasitthiyanukarn et al. recently reported that chitosan/alginate NPs loaded with curcumin diethyl diglutarate $(215 \mathrm{~nm})$ promote sustain release, digestibility, bioaccessibility, physicochemical stability, and cellular uptake of curcumin [104]. In a recent study, polyethylene glycol (PEG) was grafted to polyethyleneimine (PEI) to form a PEG-b-PEI (mPPS). Then, it was coupled with folic acid as a 
ligand to target tumor cells that display an increased expression of folate receptors. Furthermore, the FA-PEG-b-PEI carrier was assembled with curcumin loaded alginate NPs. Gomez et al. developed a novel and efficient photodynamic therapy system for psoriasis therapy. In this study, curcumin-loaded chitosan/alginate NPs were found to repress the hyperproliferation of TNF- $\alpha$ induced HaCaT cells by using blue LED light [106]. Xu et al. prepared a nano-emulsion based alginate hydrogel beads for curcumin encapsulation. The nanocarrier had $24 \mathrm{~nm}$ size with $99 \%$ drug entrapment efficiency and $\mathrm{pH}-$ responsive drug released pattern [147].

\subsubsection{Starch}

One other type of biopolymers is starch that is found abundantly in different parts of plants and is structured by interactions between glucose monomers in two forms, branched amylopectin $(70 \%-80 \%)$ and linear amylose $(20 \%-30 \%)$. This is a reactive biopolymer that can be modified with various methods and used for different applications, especially it can be applied as a drug delivery nanosystem for curcumin [148]. In this regard, there is a study conducted by Acevedo-Guevara et al., in which the acetylated starch extracted from green bananas used as a carrier for curcumin with an average size of $250 \mathrm{~nm}$. Results showed that acetylated nanocarriers had higher encapsulation efficacy and controlled release potential than natural forms [107]. Furthermore, octenyl succinylated cassava starch NPs loaded curcumin (10-50 nm) showed exclusive water solubility, bioavailability, control release, cellular uptake, and anti-cancer potential [108].

The micellar structure of curcumin starch was prepared through the self-assembly of curcumin conjugated with hydrophilic hydroxyethyl starch by using an acid-labile ester linker. This new type of nanocarrier had a uniform size less than $100 \mathrm{~nm}$ with a dramatic enhancement in the solubility of curcumin, along with increasing its storage stability, and also pH-responsive release profile [149]. Starch was also used in the form of composite with other materials for cancer prevention and treatment with curcumin [150,151]. For example, Athira et al. prepared a curcumin loaded starch-poly(vinyl alcohol) nanocomposite with the size of about 50-200 nm that improved its anti-cancer activities [152]. In a new study, a smart nanogel based on the covalent interactions between carboxymethyl starch and chitosan hydrochloride was prepared, and curcumin was loaded in it with high entrapment efficiency (89\%-95\%). Additionally, it showed a sustained released profile that was responsive to $\mathrm{pH}$ changes [153].

\subsubsection{Cellulose}

Cellulose is a type of $\beta$-glucan polysaccharide consist of glucose monomers that are attached through $(1,4)-\beta$ - linkage to each other. This is a type of biopolymer that is widely found in the cell wall structure of plants, bacteria, algae, and fungi [154]. This is a natural polymer with characteristics like low-cost, biocompatibility, low density, hydrophilicity, and suitable modification that make it an ideal candidate for drug delivery application [155].

The application of this biopolymer for delivery of curcumin as an anti-cancer drug is discussed in different studies; for example, cellulose nanocrystal film loaded with curcumin was synthesized as an antimicrobial nanocarrier in the diabetic rat model. In vitro experiments showed a prolonged release of drugs for $36 \mathrm{~h}$ accompanied by the lack of burst effects. However, in vivo investigations demonstrated a significant decline in wound size and inhibition of bacterial growth. Sebaceous glands and hair follicles were also repaired. This new wound dressing could be an alternative for heavy metal substitutes such as silver ions [109]. In an experiment by Kanagarajan et al., pH-sensitive NPs were fabricated, in which $\mathrm{MnFe}_{2} \mathrm{O}_{4}$ curcumin loaded NPs coated with carboxymethyl cellulose by glutaraldehyde crosslinking $(27 \mathrm{~nm})$. These superparamagnetic biocompatible NPs can facilitate the release of cargo at endosomal acidic conditions ( $\mathrm{pH}$ 5.5) [156]. Kang et al. hybridized curcumin loaded nanostructured lipid carriers $(\sim 500 \mathrm{~nm})$ with cellulose nanofiber films for the treatment of imiquimod-induced psoriatic in mice model. Significant deposition of curcumin to the epidermis in addition to skin hydrating booster effect of cellulose nanofiber film resulted in relief of psoriatic 
symptoms and reduction of pro-inflammatory cytokine levels [110]. Moreover, Ngwabebhoh et al. synthesized curcumin encapsulated pickering NPs with an average size of $150 \mathrm{~nm}$ to improve curcumin bioavailability. The results suggested a high encapsulation efficiency and sustained release of curcumin, thereby indicating an enhanced antimicrobial and anticancer potential of drug [111].

\section{Exosomes}

Exosomes are bilayer membrane nano-sized vesicles derived from endosomal compartments with an average diameter of 30 to $100 \mathrm{~nm}$ [157]. Its biogenesis is a tightly controlled method of inward budding from the limiting membrane of multivesicular bodies (MVBs) [158]. The internal contents are released into the extracellular space in the form of "exosomes" when MVBs are fused to the plasma membrane. Exosomes can be found in body fluids such as blood, plasma, urine, saliva, amniotic fluid, synovial fluid, malignant ascites, and pleural effusions [159]. However, they can be produced by most cells, including B cells, T cells, dendritic cells, macrophages, neurons, glial cells, the most tumor cells, and stem cells. It seems that most cell types from normal cells to unhealthy cells release exosomes. Notably, exosomes based on their phenotypes and body fluids secrete diverse bioactive molecules such as proteins, lipids, and nucleic acid. In other words, exosomes participate in the transferring of signal transduction and intercellular communication from the main cell to the receptor cell in the form of proteins, mRNAs, ncRNAs, and miRNAs. Moreover, exosome contents are protected from the destruction of extracellular factors that it guarantees their half-life and biological activity enhancement [160]. Exosomes are made up of different types of lipids, such as cholesterol, sphingolipids, phosphoglycerides, ceramides, and saturated fatty acid chains. However, they have proteins such as transport proteins, heat shock proteins, proteins associated with multi-vesicular body biogenesis, and tetraspanin. They also have nucleic acids in the form of miRNA, mRNA, and other non-coding RNAs [124].

Thus, exosomes play an essential role in intercellular communication without direct cell-to-cell contact [161]. Although exosomes are not NPs derived from the nanotechnology due to its non-mankind nature, they may act as a nanocarrier owing to their particle diameter. Therefore, exosome's particle size resulting in deep penetration into the tissues [162] and overcoming barriers such as the blood-brain barrier and the deformable cytoskeleton. Notably, they have slightly negative zeta potential that guarantees their long circulation [163]. In addition, some exosomes are capable of escaping from the immune system and have shown low immunogenicity and high stability in the blood, which prolongs the circulation of the drug within the body [164]. Furthermore, exosomes can be employed to load a variety of small bioactive molecules as a nanocarrier such as paclitaxel, doxorubicin, and curcumin, as well as peptide- or protein-based therapeutics. In addition, the loading of exosomes with a genetic material such as siRNA has also been reported [165]. To sum things up, due to their naturally biocompatible characteristics, exosomes are a promising candidate for clinical applications.

\subsection{Advantage and Disadvantage of Exosomes}

NPs seems to be promising for drug delivery of biomedical and pharmaceutical agents [77]. For example, liposomes control the release of drugs with an optimal synergistic molecular ratio and increase the concentration of the drug at the tumor site through the enhanced permeability and retention (EPR) effect. Although. liposomes reduce toxicity and side effects in the normal cells [41], the use of liposomes is limited due to some disadvantages such as poor stability, short half-life, rapid removal by the reticuloendothelial system, intracellular interactions or absorption, lipid particle growth, tendency to gelation and their intrinsic low incorporation rate due to the structure of the solid lipid $[29,166]$. Unlike conventional NPs such as liposomes and polymeric NPs, exosomes are naturally stable $[124,167,168]$ and potentially diminish endosomal pathways and lysosomal damage while carrying their cargo directly into the cytoplasm. To have a comparison to cell therapy, exosomes are easier stored and reduces risks [30]. One of the remarkable benefits related to exosome is their permeability to damaged tissues and tumor sites and the ability to cross the blood-brain barrier 
(BBB) $[124,169]$. Therefore, exosome is an effective carrier to overcome the problems associated with drug delivery to the brain in clinical trials [170]. Besides, they are stable in the blood that allows them to remain in the body for a long time under various conditions. It is worth mentioning that exosomes have a by-layer shape with the hydrophilic feature in both surface and hydrophobic features in interlayer space that makes them suitable for both lipophilic and hydrophilic drug delivery [30].

There have been investigation related to natural cells such as bacteria, viruses, and eukaryotic cells [171]. Compared to liposomes and virus-based delivery systems, the immunogenicity of exosomes is very low [30], which makes them a suitable system for in vivo applications due to their more biocompatibility. Another benefit of exosomes is that therapeutic exosomes can be isolated from the patients and used for delivery and personal injections of the drugs. Exosomes that are provided from a suitable source are essential for conducting load loads to targeted tissues because the fat and compounds present at the cell surface are exclusive to these exosomes, and it is important to maintain this feature [169]. A critical problem in clinical studies is the lack of an optimal method for obtaining pure exosomes. This is primarily due to the relatively low amounts of released exosomes by mammalian cells. Therefore, a long-term source of exosomes with excellent characteristics and effective separation method is needed to obtain a large number of pure exosomes [30].

Another challenge with exosomes as a nanocarrier is their drug loading capacity [172]. Therefore, increasing the loading capacity of cargo and non-destructive targeted capabilities is crucial for favorable drug delivery. Finding more optimized approaches to manipulate the structure and function of exosomes that may promote their clinical applications is therefore vital [30].

\subsection{Exosomes for Curcumin Delivery}

To sum things up, to increase curcumin solubility as well as bioavailability and thereby enhancing curcumin therapeutic efficacy, an optimized drug delivery system may be needed. For this purpose, curcumin can be encapsulated into liposomes, cyclodextrin, polymeric NPs, microspheres, hydrogels, and exosomes $[38,170,173]$. To achieve proper function and performance of the liposome-based delivery system, various components must be appropriately selected and controlled [37]. It is noteworthy that an exosome can carry multiple drugs to adjust the activity of various pathways [38].

The protective environment of curcumin provided by exosomes makes exosome appropriate carrier for oral administration [174]. The use of exosomal curcumin may have benefits for curcumin function, as well [38]. Encapsulated curcumin into exosomes is stable compared to the free curcumin and can protect curcumin from the environment of the human digestive system and protect the intestinal epithelium [174]. Curcumin can be encapsulated in two layers of lipid exosomes, which results in the protection of curcumin from damage. Theoretically, circulating exosomes due to endogenous origins and a particular superficial composition should be more stable than other synthetic polymer-based NPs, such as liposomes [175]. It appears that the encapsulation of curcumin into exosomes significantly increases the solubility, bioavailability, and stability of curcumin [38].

In recent years, exosome delivery as a promising approach for carrying therapeutics across the BBB to the central nervous system (CNS) has been an increasing interest among researchers. Kalani et al. demonstrated that curcumin-primed and curcumin-loaded exosomes (40-200 nm) had neuroprotective effects due to their anti-lipidemic, anti-oxidative, and anti-inflammatory nature [176]. Furthermore, curcumin-primed exosomes $(117 \pm 10 \mathrm{~nm})$ prepared for drug delivery into CNS in vitro and in vivo. Effective BBB transport achieved via receptor-mediated transcytosis, in which active targeting of ICAM-1 proteins was provided by the LFA-1 functionalization of exosomes. Results indicated that curcumin-primed exosomes prevent neural death and improve Alzheimer's disease symptoms owing to an inhibition of Tau protein phosphorylation through the AKT/GSK-3 $\beta$ pathway [177]. Intranasal administration of curcumin encapsulated into exosomes causes NMDAR1 expression accompanied by the reduction of edema, infarct size, astrogliosis, and vascular inflammation as well as tight and adherent-junctions recovery and NeuN positive neurons restoration after an ischemia-reperfusion injury in the mouse model. Potent therapeutic effects of curcumin encapsulated into exosomes are in 
part related to the numerous secreted paracrine factors derived from mesenchymal stem cells along with extraordinary curcumin anti-inflammation and neuroprotective potentials [170].

Bovine milk is a rich source of exosomes for carrying therapeutics like curcumin. Curcumin-loaded into milk exosomes (30-100 nm) possess higher bioavailability, aqueous solubility, and stability as well as easier crossing through the intestinal barrier in compare with free curcumin [174]. Interestingly, oral delivery of curcumin via milk-derived exosomes $(\sim 93 \mathrm{~nm})$ showed a strong inhibitory effect in mice bearing cervical tumor xenograft [178]. However, curcumin-exosome NPs exhibit higher solubility and antioxidant efficacy $(\sim 41 \mathrm{~nm})$ in comparison with free curcumin by using fluorescence tracking analysis [179].

\section{Co-Polymers}

In order to improve bioavailability and hydrophilicity of curcumin, colloidal drug delivery systems are used to solubilize medicines. There has been interest in the use of polymeric nano-particulate delivery systems composed of biocompatible, biodegradable, amphiphilic diblock copolymers for the intravenous administration of hydrophobic compounds [180]. Polymer-based nano-carriers demonstrate good potential as an anti-cancer therapeutics [181]. The effect may be due to their favorable properties like small size, enormous biocompatibility and biodegradability, high stability, prolonged circulation time in the bloodstream, improved drug loading capacity, as well as tendency for easy chemical modifications [181,182].

Biochemical reactions occur in the micrometer or sub-micrometer-sized environments. The various categories of molecules such as hydrophilic drugs or enzymes can be applied to design a highly efficient alternations [183]. Depending on the diblock composition and addition to aqueous media, these copolymers self-gathered to form structures in a nano-sized termed micelles [180]. Polymeric micelles defined as core-shell nanoparticles that may be used as appropriate carriers of biologically active compounds for different medical applications [182]. Poly (ethylene glycol) (PEG) and poly (e-caprolactone) (PCL) can be useful in the construction of polymeric carriers. PEG that has been approved by the United States Food and Drug Administration (FDA) is a hydrophilic, non-toxic polymer, and is used for medical purposes. It exhibits low protein adsorption and cell adhesion properties [184]. The novel chitosan-coated XGO-b-PCL nanoparticles are another example of a better strategy to improve the therapeutic efficacy of hydrophobic drugs [185].

Block copolymer nano-carriers have been used for the delivery of curcumin [182] for example cationic PDMAEMA-PCL-PDMAEMA micelles were developed and provide sustained release and modified antioxidant activity of curcumin. Yoncheva and et al. studied the effect of these particles on K562 and U266 cells and found that cytotoxic capacity of micellar curcumin is better than the effect of free curcumin at lower concentrations [181]. In another study, curcumin was incorporated into the core of PEO113-b-PnBA235-b-PAA14 micelles. The release profiles of curcumin from micelles showed sustained release without burst effect [182]. Additionally, Tabatabaei et al. prepared curcumin loaded PLGA-PEG NPs and showed that the anti-cancer efficacy of curcumin triblock copolymer NPs (70-300 nm, encapsulation efficacy 84.5\%) is significantly higher than curcumin in MCF-7 human breast cells [186]. PLGA a polymer consisting of PGA and PLA is considered as a copolymer and used for drug delivery due to its non-significant toxicity and modulation of hydrophilicity/hydrophobicity. Hu et al. prepared a curcumin-PLGA NP and investigated the inhibition of opioid tolerance in mice treated with morphine. Interestingly, administration of curcumin-PLGA NP resulted in 11-33 fold decrease in morphine dose in mice in part through the inhibition of activity of $\mathrm{Ca} 2+/$ calmodulin-dependent protein kinase II $\alpha$ [19]. Furthermore, Shen et al. prepared three types of NP including curcumin-PLGA, Curcumin- PEG-b-PLA and the combination of curcumin-PLGA-PEG-b-PLA to investigate attenuation of morphine tolerance in mice. The particle size of all NPs was similar and around $150 \mathrm{~nm}$. Results of tail-flick in mice were stronger than with non-formulated curcumin $[187,188]$. These findings are very important especially for the diseases associated with chronic pain. 
Moreover, encapsulation of curcumin into a polymer based and other abovementioned materials can enhance the bioavailability of curcumin and its drug efficacy. It appears that there are some conflicting data on the correlation between the particle size and drug bioavailability. For example, Sun et al. reported that NPs at the range of 700-120 nm enhanced bioavailability compared to the suspension form while there was no significant between the NPs at the range of 700 to $120 \mathrm{~nm}$. Otherwise, bioavailability significantly enhance when the particle size drops to $80 \mathrm{~nm}$ [189]. While, Vrana et al. demonstrated that there is not a significant correlation between the particle size and cyclosporine A formulations [190]. If it is considered that water solubility (hydrophobicity) is one the most critical factors in drug bioavailability, therefore it might be said that the contact angle of a nanocarrier is a critical marker to predict drug bioavailability and eventually this hypothesis may explain the controversy data on the correlation of particle size and bioavailability. The important point is that particle size and surface charge are just two markers in the final fate of contact angle and there are some other parameters such as roughness, morphology etc., that may affect contact angle.

\section{Targeted Delivery}

Targeted delivery can be divided into active and passive targeted delivery in which active targeted delivery is usually through some antigen or receptor on/in targeted cells while passive delivery is mediated via enhanced permeability and retention effect (EPR) mechanism. There are some molecules that can act as a ligand for targeting drug delivery such as antibodies fragment and monoclonal antibodies, aptamers, folic acid and etc. (Table 2) [37,191,192]. Curcumin as an anti-inflammatory agent has been widely used a potential drug in cancer therapy. Breast cancer cells overexpresses sialic acid in cell membrane and Kundu et al. conjugated curcumin to phenyl boronic acid (PBA) and ZnO NPs. Notably, Curcumin-PBA-ZnO NP $(40 \mathrm{~nm})$ can significantly decrease tumor growth in mice bearing Ehrlich ascites carcinoma (EAC) tumor [193]. In another study, gold nanorods and curcumin were loaded into a PLGA-b-PEG co-polymer NPs $(\sim 137 \mathrm{~nm})$. The anti-cancer efficacy of the nanocarrier with and without curcumin was investigated. The results disclosed the retention of both gold-PLGA-b-PEG NPs (with and without circumin) in cancer cells located in esophageal mucosa, but not in normal esophageal mucosa in a Barrett's associated animal model upon NIR irradiation [194]. Another example of targeted delivery is related to folic acid attached to curcumin-albumin-Bi2S3 NPs. The combination of chemotherapy and radiotherapy led to an enhanced efficacy in an animal model of tumor [195].

There are some reports related to conjugation of folate to NPs as a cargo for anti-cancer delivery. Another example of targeted curcumin delivery is related to the conjugation of curcumin to hyaluronic acid (HA) and folic acid. Both HA (CD 44 receptor) and folic acid are over-expressed in cancer cells. However, their attachments to gold NPs, HA, and PEG enhance cancer cell toxicity and drug circumstance and up-take, respectively. Interestingly, the final particle size was approximately $120 \mathrm{~nm}$ [199]. In fact, folate conjugation enhances active targeting through increased transportation of cargo using endocytosis into the cell. For example, Thulasidasan et al. conjugated folate on the surface of PLGA-PEG loaded curcumin NP and evaluated the NP in combination with paclitaxel and compared it with liposome. The results showed synergistic cytotoxicity in Hela cancer cells along with enhanced retention time in cervix tissue of Swiss albino mice [200]. Huong et al. attached folic acid to a NP containing magnetic NP, curcumin and coated it with O-carboxylmethylchitosan. Overall, the outcomes indicated that targeted delivery system can enhance bio-distribution in mice bearing a sarcoma-180 solid tumor. Notwithstanding, magnetic NPs under magnetic field can induce heat and trigger cell death mechanisms especially in cancer cells owing to two reasons: (1) Cancer cells are more susceptible to the high temperature $\left(42{ }^{\circ} \mathrm{C}\right)$ compared to the normal cells, and (2) Passive targeting of magnetic NPs owing to their particle size [201]. Song et al. conjugated folate on the surface of albumin NPs loaded curcumin as a carrier $(\sim 165 \mathrm{~nm},-27.3 \mathrm{mV})$ for cancer therapy in mice induced by HT29 cells subcutaneously. The results showed a higher anti-tumor efficacy of water soluble curcumin NPs in part due to the inhibition of drug metabolism that resulted in an enhanced anti-tumor efficacy [188]. 
Table 2. Targeted curcumin delivery using biopolymers-based nanoparticles.

\begin{tabular}{|c|c|c|c|c|c|c|c|}
\hline Polymer & The Route of Targeting & Size & Zeta Potential & LC or EE & $\begin{array}{c}\text { Cell Line/Animal } \\
\text { Model }\end{array}$ & Advantages & Refs. \\
\hline F-CUR-HSANPs & Folate & $165.6 \pm 15.7 \mathrm{~nm}$ & $-27.3 \pm 4.2 \mathrm{mV}$ & $\mathrm{EE}: 88.7 \% \pm 4.8 \%$ & $\begin{array}{l}\text { Murine colon } \\
\text { cancer model }\end{array}$ & $\begin{array}{l}\text { Maintained sustained release, and a } \\
\text { faster release of CM compare to the } \\
\text { unconjugated NPs }\end{array}$ & [188] \\
\hline Apt-HSA/CCM NP & $\begin{array}{l}\text { Aptamer to target HER-2 } \\
\text { positive cells }\end{array}$ & $281.1 \mathrm{~nm}$ & $-33.3 \pm 2.5 \mathrm{mV}$ & $3.4 \%$ & SK-BR3 cells & Higher toxicity & [120] \\
\hline Gal-BSA-Cur NPs & $\begin{array}{l}\text { Galactosylation to target } \\
\text { asialoglycoprotein receptor } \\
\text { (ASGPR) overexpressed on } \\
\text { hepatocellular carcinoma } \\
\text { (HCC) cells }\end{array}$ & $116.24 \mathrm{~nm}$ & $-14.12 \pm 1.81$ & $\mathrm{EE}: 55.47 \% \pm 0.45 \%$ & HCC cell line & $\begin{array}{l}\text { Enhanced the internalization ability of } \\
\text { drug compared with BSA NPs-loaded } \\
\text { curcumin }\end{array}$ & [196] \\
\hline $\begin{array}{l}\text { Zein and HA for the } \\
\text { co-delivery of curcumin } \\
\text { and quercetagetin }\end{array}$ & HA & $231 \mathrm{~nm}$ & $-30.5 \mathrm{mV}$ & $2.5 \%$ & $\begin{array}{l}\text { simulated } \\
\text { gastrointestinal } \\
\text { tract conditions }\end{array}$ & Improve oral bioavailability & [122] \\
\hline $\begin{array}{l}\text { Curcumin loaded magnetic } \\
\text { silk fibroin core-shell NPs }\end{array}$ & Magnetic NP & $30 \mathrm{~nm}$ to $250 \mathrm{~nm}$ & & LC: $8.4 \%$ & MDA-MB-231 cells & Enhanced growth inhibition & [128] \\
\hline Bi2S3@BSA-FA-CUR & Folic acid & $170.9 \mathrm{~nm}$ & $-23.2 \mathrm{mV}$ & LC:10 $\pm 1.51 \%$ & $\begin{array}{l}\text { The mouse breast } \\
\text { carcinoma cell line, } \\
\text { Murine breast } \\
\text { cancer model }\end{array}$ & $\begin{array}{l}\text { Enhanced the efficacy of } \\
\text { chemoradiation therapy }\end{array}$ & [195] \\
\hline $\begin{array}{l}\text { magnetic alginate/chitosan } \\
\text { layer-by-layer nanoparticles } \\
\text { (MACPs) }\end{array}$ & $\mathrm{Fe} 3 \mathrm{O} 4 \mathrm{NPs}$ & $172 \mathrm{~nm}$ to $199 \mathrm{~nm}$ & & EE: $49.2 \%$ & $\begin{array}{l}\text { MDA-MB-231 } \\
\text { breast cancer cells, } \\
\text { HDF cells }\end{array}$ & $\begin{array}{l}\text { The sustained release profiles, enhanced } \\
\text { uptake efficiency and cytotoxicity to } \\
\text { cancer cells }\end{array}$ & [197] \\
\hline $\begin{array}{l}\text { folic acid tagged aminated } \\
\text { starch/ZnO coated iron } \\
\text { oxide nanoparticles as } \\
\text { targeted curcumin } \\
\text { delivery system }\end{array}$ & $\mathrm{Fe} 3 \mathrm{O} 4 \mathrm{NPs}$ & $31.2 \pm 2$ & $42.9 \pm 0.03$ & EE: $76.8 \pm 0.04 \%$ & $\begin{array}{l}\text { HepG2 and MCF7 } \\
\text { cell lines }\end{array}$ & Enhanced the uptake by HepG2 cells & [198] \\
\hline Cur loaded MnFe2O4-CMC & $\mathrm{Fe} 2 \mathrm{O} 4 \mathrm{NPs}$ & $35 \mathrm{~nm}$ & & & $\begin{array}{l}\text { MCF7 and HeLa } \\
\text { cells }\end{array}$ & Enhanced the therapeutic efficacy & [156] \\
\hline
\end{tabular}


As mentioned earlier, aptamers also function as a ligand for targeting delivery on the surface of NPs. Lei et al. conjugated RNA aptamers for epithelial cell adhesion molecule (EpCAM) protein on the surface of PLGA-lecithin-PEG NPs (less than $100 \mathrm{~nm}$ ) containing of curcumin. They investigated its efficacy on colorectal adenocarcinoma cells. The half-life and retention time of curcumin NPs increased as compared to the free curcumin, 6 and 3-fold, respectively. However, the cancer cell cytotoxicity and bioavailability of cargo was significantly enhanced as compared to the curcumin [202]. Moreover, Huang et al. used galactosylation as a potential ligand for cell targeting. They galactosylated albumin NPs encapsulated curcumin as carrier $(116.24 \mathrm{~nm})$ for HepG2 cancer cell therapy. It was noted that galactose selectively bound to the receptors on the surface of cancer cells and inhibited NF-kB activation and cell migration, thus resulting in enhanced anti-tumor efficacy [196].

\section{Conclusions and Future Trends}

Curcumin holds a great promise among the nutraceuticals due to its pleiotropic biological activities. However, its poor solubility and bioavailability may limit its application in the clinic. To overcome these drawbacks, it seems that encapsulation into specific nanocarriers can be of great interest and enhance its applications. Here in this review, we have discussed different types of biopolymers and biological carriers in different forms that can be used for curcumin delivery. For this purpose, at first, we described protein-based biopolymers which are biocompatible carriers with the ability to form different types of nanocarriers. Then different kinds of polysaccharide biopolymers are discussed along with their characteristic features like biocompatibility, bioavailability, low cost, and biodegradability. At the end, the biological carriers with specific focus on exosomes, their excellent properties, and preparation methods have been highlighted. Overall, the encapsulation of curcumin into these various carriers may lead to a significant enhancement of its various anti-cancer activities. Although the biocompatibility and anti-cancer efficacy of the above-mentioned nanocarriers have been partially validated in different models, however, further in vivo and clinical studies are needed to facilitate their safe administration in cancer patients.

Funding: This study was funded by the Student Research Committee, Kerman University of Medical Sciences (Grant Number: 96000548), Kerman, Iran.

Conflicts of Interest: The author report no potential conflict of interest.

$\begin{array}{ll}\text { Abbreviations } & \\ \text { VEGF } & \text { Vascular endothelial growth factor } \\ \text { HAS } & \text { human serum albumin } \\ \text { BSA } & \text { bovine serum albumin } \\ \text { NPs } & \text { nanoparticles } \\ \text { HER2 } & \text { human epidermal growth factor receptor } 2 \\ \text { HA } & \text { hyaluronic acid } \\ \text { Apt-HSA/CCM } & \text { aptamer-decorated curcumin-loaded human serum albumin } \\ \text { SSPS } & \text { soluble soybean polysaccharide } \\ \text { Cur-ACRU/CS } & \text { curcumin-loaded acylated cruciferin/charged chitosan } \\ \text { CDG-CANPs } & \text { curcumin diethyl diglutarate-loaded Chitosan/alginate NPs } \\ \text { CUR-AlgNP } & \text { curcumin loaded alginate NP } \\ \text { Cur-CS/Alg NPs } & \text { curcumin-loaded chitosan/alginate NPs } \\ \text { CMC } & \text { carboxymethyl cellulose } \\ \text { Cur-NLCs } & \text { curcumin loaded nanostructured lipid carriers } \\ \text { ANC } & \text { aminated nanocellulose } \\ \text { EWP } & \text { egg white protein } \\ \text { PECs } & \text { polyelectrolyte complexes } \\ \text { SC } & \text { sodium caseinate } \\ \text { SA } & \text { sodium alginate }\end{array}$


PEG poly (ethylene glycol)

PCL poly (e-caprolactone)

FDA U.S. Food and Drug administration

\section{References}

1. Fridlender, M.; Kapulnik, Y.; Koltai, H. Plant derived substances with anti-cancer activity: From folklore to practice. Front. Plant Sci. 2015, 6, 799. [CrossRef] [PubMed]

2. Mohammadinejad, R.; Ahmadi, Z.; Tavakol, S.; Ashrafizadeh, M. Berberine as a potential autophagy modulator. J. Cell. Physiol. 2019, 234, 1491414926. [CrossRef] [PubMed]

3. Mohammadinejad, R.; Shavandi, A.; Raie, D.S.; Sangeetha, J.; Soleimani, M.; Hajibehzad, S.S.; Thangadurai, D.; Hospet, R.; Popoola, J.O.; Arzani, A. Plant molecular farming: Production of metallic nanoparticles and therapeutic proteins using green factories. Green Chem. 2019, 21, 18451865. [CrossRef]

4. Ahmadi, Z.; Mohammadinejad, R.; Ashrafizadeh, M. Drug delivery systems for resveratrol, a non-flavonoid polyphenol: Emerging evidence in last decades. J. Drug Delivery Sci. Technol. 2019, 51, 591-604. [CrossRef]

5. Brower, V. Nutraceuticals: Poised for a healthy slice of the healthcare market? Nat. Biotechnol. 1998, 16, 728. [CrossRef]

6. Murray-Stewart, T.; Casero, R. Regulation of polyamine metabolism by curcumin for cancer prevention and therapy. Med. Sci. 2017, 5, 38. [CrossRef]

7. Montalbán, M.; Coburn, J.; Lozano-Pérez, A.; Cenis, J.; Víllora, G.; Kaplan, D. Production of curcumin-loaded silk fibroin nanoparticles for cancer therapy. Nanomaterials 2018, 8, 126. [CrossRef]

8. De Matos, R.P.A.; Calmon, M.F.; Amantino, C.F.; Villa, L.L.; Primo, F.L.; Tedesco, A.C.; Rahal, P. Effect of curcumin-nanoemulsion associated with photodynamic therapy in cervical carcinoma cell lines. BioMed Res. Int. 2018, 2018, 1-11. [CrossRef] [PubMed]

9. Ramayanti, O.; Brinkkemper, M.; Verkuijlen, S.; Ritmaleni, L.; Go, M.; Middeldorp, J. Curcuminoids as EBV lytic activators for adjuvant treatment in EBV-positive carcinomas. Cancers 2018, 10, 89. [CrossRef] [PubMed]

10. Shanmugam, M.K.; Rane, G.; Kanchi, M.M.; Arfuso, F.; Chinnathambi, A.; Zayed, M.; Alharbi, S.A.; Tan, B.K.; Kumar, A.P.; Sethi, G. The multifaceted role of curcumin in cancer prevention and treatment. Molecules 2015, 20, 2728-2769. [CrossRef]

11. Shanmugam, M.K.; Kannaiyan, R.; Sethi, G. Targeting cell signaling and apoptotic pathways by dietary agents: Role in the prevention and treatment of cancer. Nutr. Cancer 2011, 63, 161-173. [CrossRef]

12. Sung, B.; Kunnumakkara, A.B.; Sethi, G.; Anand, P.; Guha, S.; Aggarwal, B.B. Curcumin circumvents chemoresistance in vitro and potentiates the effect of thalidomide and bortezomib against human multiple myeloma in nude mice model. Mol. Cancer Ther. 2009, 8, 959-970. [CrossRef]

13. Lagoa, R.; Silva, J.; Rodrigues, J.R.; Bishayee, A. Advances in phytochemical delivery systems for improved anticancer activity. Biotechnol. Adv. 2019. [CrossRef]

14. Deng, S.; Shanmugam, M.K.; Kumar, A.P.; Yap, C.T.; Sethi, G.; Bishayee, A. Targeting autophagy using natural compounds for cancer prevention and therapy. Cancer 2019, 125, 1228-1246. [CrossRef] [PubMed]

15. Tewari, D.; Nabavi, S.F.; Nabavi, S.M.; Sureda, A.; Farooqi, A.A.; Atanasov, A.G.; Vacca, R.A.; Sethi, G.; Bishayee, A. Targeting activator protein 1 signaling pathway by bioactive natural agents: Possible therapeutic strategy for cancer prevention and intervention. Pharmacol. Res. 2018, 128, 366-375. [CrossRef]

16. Shanmugam, M.K.; Warrier, S.; Kumar, A.P.; Sethi, G.; Arfuso, F. Potential role of natural compounds as anti-angiogenic agents in cancer. Curr. Vasc. Pharmacol. 2017, 15, 503-519. [CrossRef]

17. Yarla, N.S.; Bishayee, A.; Sethi, G.; Reddanna, P.; Kalle, A.M.; Dhananjaya, B.L.; Dowluru, K.S.; Chintala, R.; Duddukuri, G.R. Targeting arachidonic acid pathway by natural products for cancer prevention and therapy. In Seminars in Cancer Biology; Theresa, V., Ed.; Academic Press: Cambridge, MA, USA, 2016; Volume 40, pp. 48-81.

18. Oskouie, M.N.; Aghili Moghaddam, N.S.; Butler, A.E.; Zamani, P.; Sahebkar, A. Therapeutic use of curcumin-encapsulated and curcumin-primed exosomes. J. Cell. Physiol. 2019, 234, 8182-8191. [CrossRef]

19. Hu, X.; Huang, F.; Szymusiak, M.; Liu, Y.; Wang, Z.J. Curcumin attenuates opioid tolerance and dependence by inhibiting Ca2+/calmodulin-dependent protein kinase II $\alpha$ activity. J. Pharmacol. Exp. Ther. 2015, 352, 420-428. [CrossRef] 
20. Chen, Y.; Wu, Q.; Zhang, Z.; Yuan, L.; Liu, X.; Zhou, L. Preparation of curcumin-loaded liposomes and evaluation of their skin permeation and pharmacodynamics. Molecules 2012, 17, 5972-5987. [CrossRef]

21. Li, L.; Ahmed, B.; Mehta, K.; Kurzrock, R. Liposomal curcumin with and without oxaliplatin: Effects on cell growth, apoptosis, and angiogenesis in colorectal cancer. Mol. Cancer Ther. 2007, 6, 1276-1282. [CrossRef]

22. Bar-Sela, G.; Epelbaum, R.; Schaffer, M. Curcumin as an anti-cancer agent: Review of the gap between basic and clinical applications. Curr. Med. Chem. 2010, 17, 190-197. [CrossRef] [PubMed]

23. Jahed, V.; Zarrabi, A.; Bordbar, A.-K.; Hafezi, M.S. NMR (1H, ROESY) spectroscopic and molecular modelling investigations of supramolecular complex of $\beta$-cyclodextrin and curcumin. Food Chem. 2014, 165, 241-246. [CrossRef] [PubMed]

24. Mousavi, H.; Movahedi, B.; Zarrabi, A.; Jahandar, M. A multifunctional hierarchically assembled magnetic nanostructure towards cancer nano-theranostics. RSC Adv. 2015, 5, 77255-77263. [CrossRef]

25. Ashrafizadeh, M.; Ahmadi, Z.; Mohamadi, N.; Zarrabi, A.; Abasi, S.; Dehghannoudeh, G.; Tamaddondoust, R.N.; Khanbabaei, H.; Mohammadinejad, R.; Thakur, V.K. Chitosan-based advanced materials for docetaxel and paclitaxel delivery: Recent advances and future directions in cancer theranostics. Int. J. Biol. Macromol. 2020, 145, 282-300. [CrossRef]

26. Tavakol, S.; Zare, S.; Hoveizi, E.; Tavakol, B.; Rezayat, S.M. The impact of the particle size of curcumin nanocarriers and the ethanol on beta_1-integrin overexpression in fibroblasts: A regenerative pharmaceutical approach in skin repair and anti-aging formulations. DARU J. Pharm. Sci. 2019, 27, 159-168. [CrossRef]

27. Ajdary, M.; Moosavi, M.; Rahmati, M.; Falahati, M.; Mahboubi, M.; Mandegary, A.; Jangjoo, S.; Mohammadinejad, R.; Varma, R.J.N. Health concerns of various nanoparticles: A review of their in vitro and in vivo toxicity. Nanomaterials 2018, 8, 634. [CrossRef]

28. Mohammadinejad, R.; Moosavi, M.A.; Tavakol, S.; Vardar, D.Ö.; Hosseini, A.; Rahmati, M.; Dini, L.; Hussain, S.; Mandegary, A.; Klionsky, D.J.J.A. Necrotic, apoptotic and autophagic cell fates triggered by nanoparticles. Autophagy 2019, 15, 4-33. [CrossRef]

29. Tavakol, S.; Kiani, V.; Tavakol, B.; Derakhshan, M.A.; Joghataei, M.T.; Rezayat, S.M. Toxicity Concerns of Nanocarriers. In Nanotechnology-Based Approaches for Targeting and Delivery of Drugs and Genes; Vijay, M., Prashant, K., Eds.; Academic Press: Cambridge, MA, USA, 2017; pp. 453-484.

30. Jiang, X.-C.; Gao, J.-Q. Exosomes as novel bio-carriers for gene and drug delivery. Int. J. Pharm. 2017, 521, 167-175. [CrossRef]

31. Nadimi, A.E.; Ebrahimipour, S.Y.; Afshar, E.G.; Falahati-Pour, S.K.; Ahmadi, Z.; Mohammadinejad, R.; Mohamadi, M. Nano-scale drug delivery systems for antiarrhythmic agents. Eur. J. Med. Chem. 2018, 157, 1153-1163. [CrossRef]

32. Ashrafizadeh, M.; Ahmadi, Z.; Kotla, N.G.; Afshar, E.G.; Samarghandian, S.; Mandegary, A.; Pardakhty, A.; Mohammadinejad, R.; Sethi, G. Nanoparticles targeting STATs in cancer therapy. Cells 2019, 8, 1158. [CrossRef]

33. Tavakol, S.; Ashrafizadeh, M.; Deng, S.; Azarian, M.; Abdoli, A.; Motavaf, M.; Poormoghadam, D.; Khanbabaei, H.; Ghasemipour Afshar, E.; Mandegary, A. Autophagy modulators: Mechanistic aspects and drug delivery systems. Biomolecules 2019, 9, 530. [CrossRef]

34. Li, R.; Deng, L.; Cai, Z.; Zhang, S.; Wang, K.; Li, L.; Ding, S.; Zhou, C. Liposomes coated with thiolated chitosan as drug carriers of curcumin. Mat. Sci. Eng. C 2017, 80, 156-164. [CrossRef]

35. Hu, K.; Huang, X.; Gao, Y.; Huang, X.; Xiao, H.; McClements, D.J. Core-shell biopolymer nanoparticle delivery systems: Synthesis and characterization of curcumin fortified zein-pectin nanoparticles. Food Chem. 2015, 182, 275-281. [CrossRef]

36. Rafiee, Z.; Nejatian, M.; Daeihamed, M.; Jafari, S.M. Application of different nanocarriers for encapsulation of curcumin. Crit. Rev. Food Sci. Nut. 2018, 59, 1-30. [CrossRef] [PubMed]

37. Johnsen, K.B.; Gudbergsson, J.M.; Skov, M.N.; Pilgaard, L.; Moos, T.; Duroux, M. A comprehensive overview of exosomes as drug delivery vehicles-Endogenous nanocarriers for targeted cancer therapy. Biochim. Biophys. Acta (BBA) Rev. Cancer 2014, 1846, 75-87. [CrossRef]

38. Sun, D.; Zhuang, X.; Xiang, X.; Liu, Y.; Zhang, S.; Liu, C.; Barnes, S.; Grizzle, W.; Miller, D.; Zhang, H.-G. A novel nanoparticle drug delivery system: The anti-inflammatory activity of curcumin is enhanced when encapsulated in exosomes. Mol. Ther. 2010, 18, 1606-1614. [CrossRef] 
39. Farooqi, A.A.; Desai, N.N.; Qureshi, M.Z.; Librelotto, D.R.N.; Gasparri, M.L.; Bishayee, A.; Nabavi, S.M.; Curti, V.; Daglia, M. Exosome biogenesis, bioactivities and functions as new delivery systems of natural compounds. Biotechnol. Adv. 2018, 36, 328-334. [CrossRef]

40. Tavakol, S. Acidic $\mathrm{pH}$ derived from cancer cells may induce failed reprogramming of normal differentiated cells adjacent tumor cells and turn them into cancer cells. Med. Hypotheses 2014, 83, 668-672. [CrossRef]

41. Xiao, Y.; Xu, C.; Xiong, H.; Du, S.; Zhou, J.; Yin, L.; Yao, J. Dose-reduction antiangiogenic curcumin-low molecular weight heparin nanodrugs for enhanced combinational antitumor therapy. Eur. J. Pharm. Sci. 2018, 119, 121-134. [CrossRef]

42. Rabiee, S.; Tavakol, S.; Barati, M.; Joghataei, M.T. Autophagic, apoptotic, and necrotic cancer cell fates triggered by acidic $\mathrm{pH}$ microenvironment. J. Cell. Physiol. 2019, 234, 12061-12069. [CrossRef]

43. Seca, A.; Pinto, D. Plant secondary metabolites as anticancer agents: Successes in clinical trials and therapeutic application. Int. J. Mol. Sci. 2018, 19, 263. [CrossRef]

44. Alemi, A.; Reza, J.Z.; Haghiralsadat, F.; Jaliani, H.Z.; Karamallah, M.H.; Hosseini, S.A.; Karamallah, S.H. Paclitaxel and curcumin coadministration in novel cationic PEGylated niosomal formulations exhibit enhanced synergistic antitumor efficacy. J. Nanobiotechnol. 2018, 16, 28. [CrossRef] [PubMed]

45. Imanifard, S.; Zarrabi, A.; Zarepour, A.; Jafari, M.; Khosravi, A.; Razmjou, A. Nanoengineered Thermoresponsive Magnetic Nanoparticles for Drug Controlled Release. Macromol. Chem. Phys. 2017, 218, 1700350. [CrossRef]

46. Cancer Therapy. Available online: https://sarinamedtrip.com/ (accessed on 5 February 2020).

47. Ashrafizadeh, M.; Ahmadi, Z.; Mohammadinejad, R.; Kaviyani, N.; Tavakol, S. Monoterpenes modulating autophagy: A review study. Basic Clin. Pharmacol. Toxicol. 2020, 126, 9-20. [CrossRef] [PubMed]

48. Baek, S.H.; Ko, J.H.; Lee, J.H.; Kim, C.; Lee, H.; Nam, D.; Lee, J.; Lee, S.G.; Yang, W.M.; Um, J.Y. Ginkgolic acid inhibits invasion and migration and TGF- $\beta$-induced EMT of lung cancer cells through PI3K/Akt/mTOR inactivation. J. Cell. Physiol. 2017, 232, 346-354. [CrossRef] [PubMed]

49. Rajendran, P.; Li, F.; Shanmugam, M.K.; Vali, S.; Abbasi, T.; Kapoor, S.; Ahn, K.S.; Kumar, A.P.; Sethi, G. Honokiol inhibits signal transducer and activator of transcription-3 signaling, proliferation, and survival of hepatocellular carcinoma cells via the protein tyrosine phosphatase SHP-1. J. Cell. Physiol. 2012, 227, 2184-2195. [CrossRef] [PubMed]

50. Tan, S.M.-L.; Li, F.; Rajendran, P.; Kumar, A.P.; Hui, K.M.; Sethi, G. Identification of $\beta$-escin as a novel inhibitor of signal transducer and activator of transcription 3/Janus-activated kinase 2 signaling pathway that suppresses proliferation and induces apoptosis in human hepatocellular carcinoma cells. J. Pharmacol. Exp. Ther. 2010, 334, 285-293. [CrossRef]

51. Ahn, K.S.; Sethi, G.; Chaturvedi, M.M.; Aggarwal, B.B. Simvastatin, 3-hydroxy-3-methylglutaryl coenzyme A reductase inhibitor, suppresses osteoclastogenesis induced by receptor activator of nuclear factor- $\mathrm{kB}$ ligand through modulation of NF-kB pathway. Int. J. Cancer 2008, 123, 1733-1740. [CrossRef]

52. Manna, S.K.; Aggarwal, R.S.; Sethi, G.; Aggarwal, B.B.; Ramesh, G.T. Morin (3,5,7,2' , 4' -pentahydroxyflavone) abolishes nuclear factor- $\mathrm{kB}$ activation induced by various carcinogens and inflammatory stimuli, leading to suppression of nuclear factor- $\mathrm{kB}$-regulated gene expression and up-regulation of apoptosis. Clin. Cancer Res. 2007, 13, 2290-2297. [CrossRef]

53. Zhang, Q.-Y.; Wang, F.-X.; Jia, K.-K.; Kong, L.-D. Natural product interventions for chemotherapy and radiotherapy-induced side effects. Front. Pharmacol. 2018, 9, 1253. [CrossRef]

54. Liu, Z.; Huang, P.; Law, S.; Tian, H.; Leung, W.; Xu, C. Preventive effect of curcumin against chemotherapy-induced side-effects. Front. Pharmacol. 2018, 9, 1374. [CrossRef] [PubMed]

55. Ashrafizadeh, M.; Ahmadi, Z.; Mohammadinejad, R.; Farkhondeh, T.; Samarghandian, S. MicroRNAs mediate the anti-tumor and protective effects of ginsenosides. Nutr. Cancer 2019. [CrossRef] [PubMed]

56. Ashrafizadeh, M.; Ahmadi, Z.; Mohammadinejad, R.; Farkhondeh, T.; Samarghandian, S. Nano-soldiers Ameliorate Silibinin Delivery: A Review Study. Curr. Drug Deliv. 2020, 17, 1-8. [CrossRef] [PubMed]

57. Ashrafizadeh, M.; Tavakol, S.; Ahmadi, Z.; Roomiani, S.; Mohammadinejad, R.; Samarghandian, S. Therapeutic effects of kaempferol affecting autophagy and endoplasmic reticulum stress. Phytother. Res. 2020. [CrossRef] 
58. Ramachandran, L.; Manu, K.A.; Shanmugam, M.K.; Li, F.; Siveen, K.S.; Vali, S.; Kapoor, S.; Abbasi, T.; Surana, R.; Smoot, D.T. Isorhamnetin inhibits proliferation and invasion and induces apoptosis through the modulation of peroxisome proliferator-activated receptor $\gamma$ activation pathway in gastric cancer. J. Biol. Chem. 2012, 287, 38028-38040. [CrossRef]

59. Dai, X.; Zhang, J.; Arfuso, F.; Chinnathambi, A.; Zayed, M.; Alharbi, S.A.; Kumar, A.P.; Ahn, K.S.; Sethi, G. Targeting TNF-related apoptosis-inducing ligand (TRAIL) receptor by natural products as a potential therapeutic approach for cancer therapy. Exp. Biol. Med. 2015, 240, 760-773. [CrossRef]

60. Sethi, G.; Ahn, K.S.; Sung, B.; Aggarwal, B.B. Pinitol targets nuclear factor- $\kappa$ B activation pathway leading to inhibition of gene products associated with proliferation, apoptosis, invasion, and angiogenesis. Mol. Cancer Ther. 2008, 7, 1604-1614. [CrossRef]

61. Ahn, K.S.; Sethi, G.; Aggarwal, B.B. Reversal of chemoresistance and enhancement of apoptosis by statins through down-regulation of the NF-кB pathway. Biochem. Pharmacol. 2008, 75, 907-913. [CrossRef]

62. Jahandar, M.; Zarrabi, A.; Shokrgozar, M.A.; Mousavi, H. Synthesis, characterization and application of polyglycerol coated Fe3O4 nanoparticles as a nano-theranostics agent. Mater. Res. Express 2015, 2, 125002. [CrossRef]

63. Ashrafizadeh, M.; Ahmadi, Z.; Mohamamdinejad, R.; Farkhondeh, T.; Samarghandian, S. Curcumin Activates the Nrf2 Pathway and Induces Cellular Protection Against Oxidative Injury. Curr. Mol. Med. 2020, 20, 1-18. [CrossRef]

64. Ashrafizadeh, M.; Ahmadi, Z.; Samarghandian, S.; Mohammadinejad, R.; Yaribeygi, H.; Sathyapalan, T.; Sahebkar, A. MicroRNA-mediated regulation of Nrf2 signaling pathway: Implications in disease therapy and protection against oxidative stress. Life Sci. 2020, 244, 117329. [CrossRef] [PubMed]

65. Batra, H.; Pawar, S.; Bahl, D. Curcumin in combination with anti-cancer drugs: A nanomedicine review. Pharmacol. Res. 2019, 139, 91-105. [CrossRef] [PubMed]

66. Radomska-Leśniewska, D.M.; Bałan, B.J.; Skopiński, P. Angiogenesis modulation by exogenous antioxidants. Central-Eur. J. Immunol. 2017, 42, 370. [CrossRef] [PubMed]

67. Rafati, N.; Zarrabi, A.; Caldera, F.; Trotta, F.; Ghias, N. Pyromellitic dianhydride crosslinked cyclodextrin nanosponges for curcumin controlled release; formulation, physicochemical characterization and cytotoxicity investigations. J. Microencapsul. 2019, 36, 715-727. [CrossRef] [PubMed]

68. Gevrek, F.; Erdemir, F. Investigation of the effects of curcumin, vitamin E and their combination in cisplatin-induced testicular apoptosis using immunohistochemical technique. Turkish J. Urol. 2018, 44, 16. [CrossRef] [PubMed]

69. Jordan, B.C.; Mock, C.D.; Thilagavathi, R.; Selvam, C. Molecular mechanisms of curcumin and its semisynthetic analogues in prostate cancer prevention and treatment. Life Sci. 2016, 152, 135-144. [CrossRef]

70. Cao, M.-T.; Liu, H.-F.; Liu, Z.-G.; Xiao, P.; Chen, J.-J.; Tan, Y.; Jiang, X.-X.; Jiang, Z.-C.; Qiu, Y.; Huang, H.-J. Curcumin downregulates the expression of Snail via suppressing Smad2 pathway to inhibit TGF- $\beta 1$-induced epithelial-mesenchymal transitions in hepatoma cells. Oncotarget 2017, 8, 108498. [CrossRef]

71. Pastorelli, D.; Fabricio, A.S.; Giovanis, P.; D'Ippolito, S.; Fiduccia, P.; Soldà, C.; Buda, A.; Sperti, C.; Bardini, R.; Da Dalt, G. Phytosome complex of curcumin as complementary therapy of advanced pancreatic cancer improves safety and efficacy of gemcitabine: Results of a prospective phase II trial. Pharmacol. Res. 2018, 132, 72-79. [CrossRef]

72. Mohammadinejad, R.; Kumar, A.; Ranjbar-Mohammadi, M.; Ashrafizadeh, M.; Han, S.S.; Khang, G.; Roveimiab, Z. Recent advances in natural gum-based Biomaterials for tissue engineering and regenerative medicine: A Review. Polymers 2020, 12, 176. [CrossRef]

73. Sun, M.; Estrov, Z.; Ji, Y.; Coombes, K.R.; Harris, D.H.; Kurzrock, R. Curcumin (diferuloylmethane) alters the expression profiles of microRNAs in human pancreatic cancer cells. Mol. Cancer Ther. 2008, 7, 464-473. [CrossRef]

74. Kawamori, T.; Lubet, R.; Steele, V.E.; Kelloff, G.J.; Kaskey, R.B.; Rao, C.V.; Reddy, B.S. Chemopreventive effect of curcumin, a naturally occurring anti-inflammatory agent, during the promotion/progression stages of colon cancer. Cancer Res. 1999, 59, 597-601. [PubMed]

75. Arya, G.; Das, M.; Sahoo, S.K. Evaluation of curcumin loaded chitosan/PEG blended PLGA nanoparticles for effective treatment of pancreatic cancer. Biomed. Pharmacother. 2018, 102, 555-566. [CrossRef] [PubMed] 
76. Dehshahri, A.; Ashrafizadeh, M.; Afshar, E.G.; Pardakhty, A.; Mandegary, A.; Mohammadinejad, R.; Sethi, G. Topoisomerase inhibitors: Pharmacology and emerging nanoscale delivery systems. Pharmacol. Res. 2020, 151, 104551. [CrossRef] [PubMed]

77. Salehiabar, M.; Nosrati, H.; Javani, E.; Aliakbarzadeh, F.; Manjili, H.K.; Davaran, S.; Danafar, H. Production of biological nanoparticles from bovine serum albumin as controlled release carrier for curcumin delivery. Int. J. Biol. Macromol. 2018, 115, 83-89. [CrossRef]

78. Elias, E.J.; Anil, S.; Ahmad, S.; Daud, A. Colon targeted curcumin delivery using guar gum. Nat. Product Commun. 2010, 5, 915-918. [CrossRef]

79. Doostmohammadi, M.; Ameri, A.; Mohammadinejad, R.; Dehghannoudeh, N.; Banat, I.M.; Ohadi, M.; Dehghannoudeh, G. Hydrogels for peptide hormones delivery: Therapeutic and tissue engineering applications. Drug Des. Dev. Ther. 2019, 13, 3405-3418. [CrossRef]

80. Pour, M.M.; Saberi-Riseh, R.; Mohammadinejad, R.; Hosseini, A. Nano-Encapsulation of Plant Growth-Promoting Rhizobacteria and Their Metabolites Using Alginate-Silica Nanoparticles and Carbon Nanotube Improves UCB1 Pistachio Micropropagation. J. Microbiol. Biotechnol. 2019, 29, 1096-1103.

81. Pour, M.M.; Saberi-Riseh, R.; Mohammadinejad, R.; Hosseini, A. Investigating the formulation of alginate-gelatin encapsulated pseudomonas fluorescens (VUPF5 and T17-4 strains) for controlling Fusarium solani on potato. Int. J. Biol. Macromol. 2019, 133, 603-613. [CrossRef]

82. Mohammadinejad, R.; Dadashzadeh, A.; Moghassemi, S.; Ashrafizadeh, M.; Dehshahri, A.; Pardakhty, A.; Sassan, H.A.; Sohrevardi, S.M.; Mandegary, A. Shedding light on gene therapy: Carbon dots for the minimally invasive image-guided delivery of plasmids and noncoding RNAs. J. Adv. Res. 2019, 18, 81-93. [CrossRef]

83. Zou, L.; Xie, A.; Zhu, Y.; McClements, D.J. Cereal proteins in nanotechnology: Formulation of encapsulation and delivery systems. Curr. Opin. Food Sci. 2019, 25, 28-34. [CrossRef]

84. Shakeri, S.; Ashrafizadeh, M.; Zarrabi, A.; Roghanian, R.; Afshar, E.G.; Pardakhty, A.; Mohammadinejad, R.; Kumar, A.; Thakur, V.K. Multifunctional polymeric nanoplatforms for brain diseases diagnosis, therapy and theranostics. Biomedicines 2020, 8, 13. [CrossRef] [PubMed]

85. Tavakol, S.; Rasoulian, B.; Ramezani, F.; Hoveizi, E.; Tavakol, B.; Rezayat, S.M. Core and biological motif of self-assembling peptide nanofiber induce a stronger electrostatic interaction than BMP2 with BMP2 receptor 1A. Mater. Sci. Eng. C 2019, 101, 148-158. [CrossRef] [PubMed]

86. Tavakol, S.; Saber, R.; Hoveizi, E.; Tavakol, B.; Aligholi, H.; Ai, J.; Rezayat, S.M. Self-assembling peptide nanofiber containing long motif of laminin induces neural differentiation, tubulin polymerization, and neurogenesis: In vitro, ex vivo, and in vivo studies. Mol. Neurobiol. 2016, 53, 5288-5299. [CrossRef] [PubMed]

87. Tavakol, S.; Mousavi, S.M.M.; Tavakol, B.; Hoveizi, E.; Ai, J.; Sorkhabadi, S.M.R. Mechano-transduction signals derived from self-assembling peptide nanofibers containing long motif of laminin influence neurogenesis in in-vitro and in-vivo. Mol. Neurobiol. 2017, 54, 2483-2496. [CrossRef] [PubMed]

88. Tavakol, S.; Nikpour, M.R.; Hoveizi, E.; Tavakol, B.; Rezayat, S.M.; Adabi, M.; Abokheili, S.S.; Jahanshahi, M. Investigating the effects of particle size and chemical structure on cytotoxicity and bacteriostatic potential of nano hydroxyapatite/chitosan/silica and nano hydroxyapatite/chitosan/silver; as antibacterial bone substitutes. J. Nanopart. Res. 2014, 16, 2622. [CrossRef]

89. Nitta, S.; Numata, K. Biopolymer-based nanoparticles for drug/gene delivery and tissue engineering. Int. J. Mol. Sci. 2013, 14, 1629-1654. [CrossRef] [PubMed]

90. Niu, B.; Guo, J.; Guo, X.; Sun, X.; Rao, C.; Liu, C.; Zhang, J.; Zhang, C.; Fan, Y.-Y.; Li, W. (NaPO3) 6-assisted formation of dispersive casein-amorphous calcium phosphate nanoparticles: An excellent platform for curcumin delivery. J. Drug Deliv. Sci. Technol. 2020, 55, 101412. [CrossRef]

91. Fan, Y.; Yi, J.; Zhang, Y.; Yokoyama, W. Fabrication of curcumin-loaded bovine serum albumin (BSA)-dextran nanoparticles and the cellular antioxidant activity. Food Chem. 2018, 239, 1210-1218. [CrossRef]

92. Das, R.P.; Gandhi, V.V.; Singh, B.G.; Kunwar, A.; Kumar, N.N.; Priyadarsini, K. Preparation of albumin nanoparticles: Optimum size for cellular uptake of entrapped drug (Curcumin). Colloids Surf. A: Physicochem. Eng. Asp. 2019, 567, 86-95. [CrossRef]

93. Yao, K.; Chen, W.; Song, F.; McClements, D.J.; Hu, K. Tailoring zein nanoparticle functionality using biopolymer coatings: Impact on curcumin bioaccessibility and antioxidant capacity under simulated gastrointestinal conditions. Food Hydrocolloids 2018, 79, 262-272. [CrossRef] 
94. Xue, J.; Zhang, Y.; Huang, G.; Liu, J.; Slavin, M.; Yu, L.L. Zein-caseinate composite nanoparticles for bioactive delivery using curcumin as a probe compound. Food Hydrocolloids 2018, 83, 25-35. [CrossRef]

95. Chang, C.; Wang, T.; Hu, Q.; Zhou, M.; Xue, J.; Luo, Y. Pectin coating improves physicochemical properties of caseinate/zein nanoparticles as oral delivery vehicles for curcumin. Food Hydrocolloids 2017, 70, 143-151. [CrossRef]

96. Liu, Q.; Jing, Y.; Han, C.; Zhang, H.; Tian, Y. Encapsulation of curcumin in zein/caseinate/sodium alginate nanoparticles with improved physicochemical and controlled release properties. Food Hydrocolloids 2019, 93, 432-442. [CrossRef]

97. Crivelli, B.; Bari, E.; Perteghella, S.; Catenacci, L.; Sorrenti, M.; Mocchi, M.; Faragò, S.; Tripodo, G.; Prina-Mello, A.; Torre, M.L. Silk fibroin nanoparticles for celecoxib and curcumin delivery: ROS-scavenging and anti-inflammatory activities in an in vitro model of osteoarthritis. Eur. J. Pharm. Biopharm. 2019, 137, 37-45. [CrossRef] [PubMed]

98. Wu, J.; Wang, J.; Zhang, J.; Zheng, Z.; Kaplan, D.L.; Li, G.; Wang, X. Oral delivery of curcumin using silk nano-and microparticles. ACS Biomater. Sci. Eng. 2018, 4, 3885-3894. [CrossRef]

99. Peng, H.; Gan, Z.; Xiong, H.; Luo, M.; Yu, N.; Wen, T.; Wang, R.; Li, Y. Self-assembly of protein nanoparticles from rice bran waste and their use as delivery system for curcumin. ACS Sustain. Chem. Eng. 2017, 5, 6605-6614. [CrossRef]

100. Chen, S.; Han, Y.; Sun, C.; Dai, L.; Yang, S.; Wei, Y.; Mao, L.; Yuan, F.; Gao, Y. Effect of molecular weight of hyaluronan on zein-based nanoparticles: Fabrication, structural characterization and delivery of curcumin. Carbohydr. Polym. 2018, 201, 599-607. [CrossRef]

101. Pan, K.; Chen, H.; Baek, S.J.; Zhong, Q. Self-assembled curcumin-soluble soybean polysaccharide nanoparticles: Physicochemical properties and in vitro anti-proliferation activity against cancer cells. Food Chem. 2018, 246, 82-89. [CrossRef]

102. Wang, F.; Yang, Y.; Ju, X.; Udenigwe, C.C.; He, R. Polyelectrolyte complex nanoparticles from chitosan and acylated rapeseed cruciferin protein for curcumin delivery. J. Agric. Food Chem. 2018, 66, 2685-2693. [CrossRef]

103. Nair, R.S.; Morris, A.; Billa, N.; Leong, C.-O. An Evaluation of curcumin-encapsulated chitosan nanoparticles for transdermal delivery. AAPS PharmSciTech 2019, 20, 69. [CrossRef]

104. Sorasitthiyanukarn, F.N.; Bhuket, P.R.N.; Muangnoi, C.; Rojsitthisak, P.; Rojsitthisak, P. Chitosan/alginate nanoparticles as a promising carrier of novel curcumin diethyl diglutarate. Int. J. Biol. Macromol. 2019, 131, 1125-1136. [CrossRef] [PubMed]

105. Anirudhan, T.S.; Anila, M.; Franklin, S. Synthesis characterization and biological evaluation of alginate nanoparticle for the targeted delivery of curcumin. Mater. Sci. Eng. C 2017, 78, 1125-1134. [CrossRef] [PubMed]

106. Gomez, C.; Muangnoi, C.; Sorasitthiyanukarn, F.N.; Wongpiyabovorn, J.; Rojsitthisak, P.; Rojsitthisak, P. Synergistic effects of photo-irradiation and curcumin-chitosan/alginate nanoparticles on tumor necrosis factor-alpha-induced psoriasis-like proliferation of keratinocytes. Molecules 2019, 24, 1388. [CrossRef] [PubMed]

107. Acevedo-Guevara, L.; Nieto-Suaza, L.; Sanchez, L.T.; Pinzon, M.I.; Villa, C.C. Development of native and modified banana starch nanoparticles as vehicles for curcumin. Int. J. Biol. Macromol. 2018, 111, 498-504. [CrossRef]

108. Athira, G.K.; Jyothi, A.N.; Vishnu, V.R. Water Soluble octenyl succinylated cassava starch-curcumin nanoformulation with enhanced bioavailability and anticancer potential. Starch-Stärke 2018, 70, 1700178. [CrossRef]

109. Tong, W.Y.; bin Abdullah, A.Y.K.; binti Rozman, N.A.S.; bin Wahid, M.I.A.; Hossain, M.S.; Ring, L.C.; Lazim, Y.; Tan, W.-N. Antimicrobial wound dressing film utilizing cellulose nanocrystal as drug delivery system for curcumin. Cellulose 2018, 25, 631-638. [CrossRef]

110. Kang, N.-W.; Kim, M.-H.; Sohn, S.-Y.; Kim, K.-T.; Park, J.-H.; Lee, S.-Y.; Lee, J.-Y.; Kim, D.-D. Curcumin-loaded lipid-hybridized cellulose nanofiber film ameliorates imiquimod-induced psoriasis-like dermatitis in mice. Biomaterials 2018, 182, 245-258. [CrossRef]

111. Ngwabebhoh, F.A.; Erdagi, S.I.; Yildiz, U. Pickering emulsions stabilized nanocellulosic-based nanoparticles for coumarin and curcumin nanoencapsulations: In vitro release, anticancer and antimicrobial activities. Carbohydr. Polym. 2018, 201, 317-328. [CrossRef] 
112. Liu, G.; Wang, Q.; Hu, Z.; Cai, J.; Qin, X. Maillard-reacted whey protein isolates and epigallocatechin gallate complex enhance the thermal stability of the pickering emulsion delivery of curcumin. J. Agri. Food Chem. 2019, 67, 5212-5220. [CrossRef]

113. Tran, D.H.N.; Nguyen, T.H.; Vo, T.N.N.; Pham, L.P.T.; Vo, D.M.H.; Nguyen, C.K.; Bach, L.G.; Nguyen, D.H. Self-assembled poly (ethylene glycol) methyl ether-grafted gelatin nanogels for efficient delivery of curcumin in cancer treatment. J. Appl. Polym. Sci. 2019, 136, 47544. [CrossRef]

114. Camargo, L.E.A.d.; Brustolin Ludwig, D.; Tominaga, T.T.; Carletto, B.; Favero, G.M.; Mainardes, R.M.; Khalil, N.M. Bovine serum albumin nanoparticles improve the antitumour activity of curcumin in a murine melanoma model. J. Microencapsul. 2018, 35, 467-474. [CrossRef] [PubMed]

115. Chang, C.; Meikle, T.G.; Su, Y.; Wang, X.; Dekiwadia, C.; Drummond, C.J.; Conn, C.E.; Yang, Y.J. Encapsulation in egg white protein nanoparticles protects anti-oxidant activity of curcumin. Food Chem. 2019, 280, 65-72. [CrossRef] [PubMed]

116. Shih, F.-Y.; Su, I.-J.; Chu, L.-L.; Lin, X.; Kuo, S.-C.; Hou, Y.-C.; Chiang, Y.-T. Development of pectin-type B gelatin polyelectrolyte complex for curcumin delivery in anticancer therapy. Int. J. Mol. Sci. 2018, 19, 3625. [CrossRef] [PubMed]

117. Elsadek, B.; Kratz, F. Impact of albumin on drug delivery-New applications on the horizon. J. Controlled Release 2012, 157, 4-28. [CrossRef]

118. Park, K. Albumin: A versatile carrier for drug delivery. J. Controlled Release 2012, 1, 3. [CrossRef]

119. Kim, T.H.; Jiang, H.H.; Youn, Y.S.; Park, C.W.; Tak, K.K.; Lee, S.; Kim, H.; Jon, S.; Chen, X.; Lee, K.C. Preparation and characterization of water-soluble albumin-bound curcumin nanoparticles with improved antitumor activity. Int. J. Pharm. 2011, 403, 285-291. [CrossRef]

120. Saleh, T.; Soudi, T.; Shojaosadati, S.A. Aptamer functionalized curcumin-loaded human serum albumin (HSA) nanoparticles for targeted delivery to HER-2 positive breast cancer cells. Int. J. Biol. Macromol. 2019, 130, 109-116. [CrossRef]

121. Lai, L.; Guo, H. Preparation of new 5-fluorouracil-loaded zein nanoparticles for liver targeting. Int. J. Pharm. 2011, 404, 317-323. [CrossRef]

122. Chen, S.; Han, Y.; Huang, J.; Dai, L.; Du, J.; McClements, D.J.; Mao, L.; Liu, J.; Gao, Y. Fabrication and characterization of layer-by-layer composite nanoparticles based on zein and hyaluronic acid for co-delivery of curcumin and quercetagetin. ACS Appl. Mater. Int. 2019, 11, 16922-16933. [CrossRef]

123. Gomez-Estaca, J.; Balaguer, M.; Gavara, R.; Hernandez-Munoz, P. Formation of zein nanoparticles by electrohydrodynamic atomization: Effect of the main processing variables and suitability for encapsulating the food coloring and active ingredient curcumin. Food Hydrocolloids 2012, 28, 82-91. [CrossRef]

124. Zou, L.; Zheng, B.; Zhang, R.; Zhang, Z.; Liu, W.; Liu, C.; Xiao, H.; McClements, D.J. Enhancing the bioaccessibility of hydrophobic bioactive agents using mixed colloidal dispersions: Curcumin-loaded zein nanoparticles plus digestible lipid nanoparticles. Food Res. Int. 2016, 81, 74-82. [CrossRef]

125. Seok, H.-Y.; Sanoj Rejinold, N.; Lekshmi, K.M.; Cherukula, K.; Park, I.-K.; Kim, Y.-C. CD44 targeting biocompatible and biodegradable hyaluronic acid cross-linked zein nanogels for curcumin delivery to cancer cells: In vitro and in vivo evaluation. J. Controlled Release 2018, 280, 20-30. [CrossRef] [PubMed]

126. Chen, S.; Li, Q.; McClements, D.J.; Han, Y.; Dai, L.; Mao, L.; Gao, Y. Co-delivery of curcumin and piperine in zein-carrageenan core-shell nanoparticles: Formation, structure, stability and in vitro gastrointestinal digestion. Food Hydrocolloids 2020, 99, 105334. [CrossRef]

127. Zhang, X.; Chen, Z.; Bao, H.; Liang, J.; Xu, S.; Cheng, G.; Zhu, Y. Fabrication and characterization of silk fibroin/curcumin sustained-release film. Materials 2019, 12, 3340. [CrossRef]

128. Song, W.; Muthana, M.; Mukherjee, J.; Falconer, R.J.; Biggs, C.A.; Zhao, X. Magnetic-silk core-shell nanoparticles as potential carriers for targeted delivery of curcumin into human breast cancer cells. ACS Biomater. Sci. Eng. 2017, 3, 1027-1038. [CrossRef]

129. Xie, X.; Yu, J.; Zhao, Z.; Zheng, Z.; Xie, M.; Wang, X.; Han, Z.; Li, G. Fabrication and drug release properties of curcumin-loaded silk fibroin nanofibrous membranes. Adsorpt. Sci. Technol. 2019, 37, 412-424. [CrossRef]

130. Wang, Z.; Zhang, R.X.; Zhang, C.; Dai, C.; Ju, X.; He, R. Fabrication of stable and self-assembling rapeseed protein nanogel for hydrophobic curcumin delivery. J. Agric. Food Chem. 2019, 67, 887-894. [CrossRef]

131. Kadam, D.; Palamthodi, S.; Lele, S. Complexation of curcumin with Lepidium sativum protein hydrolysate as a novel curcumin delivery system. Food Chem. 2019, 298, 125091. [CrossRef] 
132. Pan, Y.; Xie, Q.-T.; Zhu, J.; Li, X.-M.; Meng, R.; Zhang, B.; Chen, H.-Q.; Jin, Z.-Y. Study on the fabrication and in vitro digestion behavior of curcumin-loaded emulsions stabilized by succinylated whey protein hydrolysates. Food Chem. 2019, 287, 76-84. [CrossRef]

133. Weng, Q.; Cai, X.; Zhang, F.; Wang, S. Fabrication of self-assembled Radix Pseudostellariae protein nanoparticles and the entrapment of curcumin. Food Chem. 2019, 274, 796-802. [CrossRef]

134. Wang, L.; Gulati, P.; Santra, D.; Rose, D.; Zhang, Y. Nanoparticles prepared by proso millet protein as novel curcumin delivery system. Food Chem. 2018, 240, 1039-1046. [CrossRef] [PubMed]

135. Ghaffari, R.; Eslahi, N.; Tamjid, E.; Simchi, A.A. Dual-sensitive hydrogel nanoparticles based on conjugated thermoresponsive copolymers and protein filaments for triggerable drug delivery. ACS Appl. Mater. Int. 2018, 10, 19336-19346. [CrossRef] [PubMed]

136. Li, X.; Mejia, L.M.; Meiser, M.; Rouf, T.; Hua, Y.; Kokini, J. Development of hollow kafirin-based nanoparticles fabricated through layer-by-layer assembly as delivery vehicles for curcumin. Food Hydrocolloids 2019, 96, 93-101. [CrossRef]

137. Hassanzadeh Davarania, F.; Ashrafizadeh, M.; Saberi Riseh, R. Antifungal nanoparticles reduce aflatoxin contamination in pistachio. PHJ 2018, 1, 25-33.

138. Roldo, M.; Hornof, M.; Caliceti, P.; Bernkop-Schnürch, A. Mucoadhesive thiolated chitosans as platforms for oral controlled drug delivery: Synthesis and in vitro evaluation. Eur. J. Pharm. Biopharm. 2004, 57, 115-121. [CrossRef]

139. Crini, G. Historical review on chitin and chitosan biopolymers. Environ. Chem. Lett. 2019, 17, $1623-1643$. [CrossRef]

140. Fathi, M.; Majidi, S.; Zangabad, P.S.; Barar, J.; Erfan-Niya, H.; Omidi, Y. Chitosan-based multifunctional nanomedicines and theranostics for targeted therapy of cancer. Med. Res. Rev. 2018, 38, 2110-2136. [CrossRef]

141. Mohammadi, Z.A.; Aghamiri, S.F.; Zarrabi, A.; Talaie, M.R. A comparative study on non-covalent functionalization of carbon nanotubes by chitosan and its derivatives for delivery of doxorubicin. Chem. Phys. Lett. 2015, 642, 22-28. [CrossRef]

142. Vijayakurup, V.; Thulasidasan, A.T.; Retnakumari, A.P.; Nandan, C.D.; Somaraj, J.; Antony, J.; Alex, V.V.; Vinod, B.S.; Liju, V.B.; Sundaram, S. Chitosan Encapsulation Enhances the Bioavailability and Tissue Retention of Curcumin and Improves its Efficacy in Preventing B [a] P-induced Lung Carcinogenesis. Cancer Prev. Res. 2019, 12, 225-236. [CrossRef]

143. Ahmadi Nasab, N.; Hassani Kumleh, H.; Beygzadeh, M.; Teimourian, S.; Kazemzad, M. Delivery of curcumin by a $\mathrm{pH}$-responsive chitosan mesoporous silica nanoparticles for cancer treatment. Artif. Cells Nanomed. Biotechnol. 2018, 46, 75-81. [CrossRef]

144. Razi, M.A.; Wakabayashi, R.; Tahara, Y.; Goto, M.; Kamiya, N. Genipin-stabilized caseinate-chitosan nanoparticles for enhanced stability and anti-cancer activity of curcumin. Colloids Surf. B. Biointerfaces 2018, 164, 308-315. [CrossRef] [PubMed]

145. Pei, M.; Jia, X.; Zhao, X.; Li, J.; Liu, P. Alginate-based cancer-associated, stimuli-driven and turn-on theranostic prodrug nanogel for cancer detection and treatment. Carbohydr. Polym. 2018, 183, 131-139. [CrossRef] [PubMed]

146. George, M.; Abraham, T.E. Polyionic hydrocolloids for the intestinal delivery of protein drugs: Alginate and chitosan-A review. J. Controlled Release 2006, 114, 1-14. [CrossRef] [PubMed]

147. Xu, W.; Huang, L.; Jin, W.; Ge, P.; Shah, B.R.; Zhu, D.; Jing, J. Encapsulation and release behavior of curcumin based on nanoemulsions-filled alginate hydrogel beads. Int. J. Biol. Macromol. 2019, 134, 210-215. [CrossRef]

148. Villa, C.C.; Sanchez, L.T.; Rodriguez-Marin, N.D. Starch nanoparticles and nanocrystals as bioactive molecule carriers. In Polymers for Agri-Food Applications; Tomy, J.G., Ed.; Springer: Berlin, Germany, 2019; pp. 91-98. [CrossRef]

149. Chen, S.; Wu, J.; Tang, Q.; Xu, C.; Huang, Y.; Huang, D.; Luo, F.; Wu, Y.; Yan, F.; Weng, Z.; et al. Nano-micelles based on hydroxyethyl starch-curcumin conjugates for improved stability, antioxidant and anticancer activity of curcumin. Carbohydr. Polym. 2020, 228, 115398. [CrossRef] [PubMed]

150. Mohanty, D.P.; Biswal, S.; Nayak, L. Preparation of starch-chitosan nanocomposites for control drug release of curcumin. Int. J. Curr. Eng. Technol. 2015, 5, 336-343.

151. Jahanizadeh, S.; Yazdian, F.; Marjani, A.; Omidi, M.; Rashedi, H. Curcumin-loaded chitosan/carboxymethyl starch/montmorillonite bio-nanocomposite for reduction of dental bacterial biofilm formation. Int. J. Biol. Macromol. 2017, 105, 757-763. [CrossRef] 
152. Athira, G.K.; Jyothi, A.N. Cassava starch-poly (vinyl alcohol) nanocomposites for the controlled delivery of curcumin in cancer prevention and treatment. Starch-Stärke 2015, 67, 549-558. [CrossRef]

153. Li, X.-M.; Wu, Z.-Z.; Zhang, B.; Pan, Y.; Meng, R.; Chen, H.-Q. Fabrication of chitosan hydrochloride and carboxymethyl starch complex nanogels as potential delivery vehicles for curcumin. Food Chem. 2019, 293, 197-203. [CrossRef]

154. Abou-Saleh, R.H.; Hernandez-Gomez, M.C.; Amsbury, S.; Paniagua, C.; Bourdon, M.; Miyashima, S.; Helariutta, Y.; Fuller, M.; Budtova, T.; Connell, S.D. Interactions between callose and cellulose revealed through the analysis of biopolymer mixtures. Nat. Commun. 2018, 9, 4538. [CrossRef]

155. Chen, N.; Wang, H.; Ling, C.; Vermerris, W.; Wang, B.; Tong, Z. Cellulose-based injectable hydrogel composite for $\mathrm{pH}$-responsive and controllable drug delivery. Carbohydr. Polym. 2019, 225, 115207. [CrossRef] [PubMed]

156. Kanagarajan, S.V.; Thiyagarajan, D. Carboxymethyl cellulose-functionalised magnetic nanocarriers for $\mathrm{pH}$ responsive delivery of Curcumin in cancer therapy. Mater. Res. Express 2018, 6, 016105. [CrossRef]

157. Sun, Y.; Zheng, W.; Guo, Z.; Ju, Q.; Zhu, L.; Gao, J.; Zhou, L.; Liu, F.; Xu, Y.; Zhan, Q. A novel TP53 pathway influences the HGS-mediated exosome formation in colorectal cancer. Sci. Rep. 2016, 6, 28083. [CrossRef] [PubMed]

158. Zomer, A.; Vendrig, T.; Hopmans, E.S.; van Eijndhoven, M.; Middeldorp, J.M.; Pegtel, D.M. Exosomes: Fit to deliver small RNA. Commun. Int. Biol. 2010, 3, 447-450. [CrossRef] [PubMed]

159. Zhang, C.; Ji, Q.; Yang, Y.; Li, Q.; Wang, Z. Exosome: Function and role in cancer metastasis and drug resistance. Technol. Cancer Res. Treat. 2018. [CrossRef]

160. Tang, X.-J.; Sun, X.-Y.; Huang, K.-M.; Zhang, L.; Yang, Z.-S.; Zou, D.-D.; Wang, B.; Warnock, G.L.; Dai, L.-J.; Luo, J. Therapeutic potential of CAR-T cell-derived exosomes: A cell-free modality for targeted cancer therapy. Oncotarget 2015, 6, 44179. [CrossRef]

161. Bang, C.; Thum, T. Exosomes: New players in cell-cell communication. Int. J. Biochem. Cell Biol. 2012, 44, 2060-2064. [CrossRef]

162. Vader, P.; Mol, E.A.; Pasterkamp, G.; Schiffelers, R.M. Extracellular vesicles for drug delivery. Adv. Drug Delivery Rev. 2016, 106, 148-156. [CrossRef]

163. Malhotra, H.; Sheokand, N.; Kumar, S.; Chauhan, A.S.; Kumar, M.; Jakhar, P.; Boradia, V.M.; Raje, C.I.; Raje, M. Exosomes: Tunable nano vehicles for macromolecular delivery of transferrin and lactoferrin to specific intracellular compartment. J. Biomed. Nanotechnol. 2016, 12, 1101-1114. [CrossRef]

164. Hood, J.L. Post isolation modification of exosomes for nanomedicine applications. Nanomedicine 2016, 11, 1745-1756. [CrossRef]

165. Goh, W.J.; Zou, S.; Ong, W.Y.; Torta, F.; Alexandra, A.F.; Schiffelers, R.M.; Storm, G.; Wang, J.-W.; Czarny, B.; Pastorin, G. Bioinspired cell-derived nanovesicles versus exosomes as drug delivery systems: A cost-effective alternative. Sci. Rep. 2017, 7, 14322. [CrossRef] [PubMed]

166. Naseri, N.; Valizadeh, H.; Zakeri-Milani, P. Solid lipid nanoparticles and nanostructured lipid carriers: Structure, preparation and application. Adv. Pharm. Bull. 2015, 5, 305. [CrossRef] [PubMed]

167. Syn, N.; Wang, L.; Sethi, G.; Thiery, J.-P.; Goh, B.-C. Exosome-mediated metastasis: From epithelial-mesenchymal transition to escape from immunosurveillance. Trends Pharm. Sci. 2016, 37, 606-617. [CrossRef] [PubMed]

168. Wee, I.; Syn, N.; Sethi, G.; Goh, B.C.; Wang, L. Role of tumor-derived exosomes in cancer metastasis. Biochim. Biophys. Acta-Rev. Cancer 2019, 1871, 12-19. [CrossRef]

169. Sun, L.; He, Q.; Qin, Z.; Lei, J.; Feng, B. Exosome and its applications as a novel drug delivery system. Clin. Oncol. 2017, 2, 1346.

170. Kalani, A.; Chaturvedi, P.; Kamat, P.K.; Maldonado, C.; Bauer, P.; Joshua, I.G.; Tyagi, S.C.; Tyagi, N. Curcumin-loaded embryonic stem cell exosomes restored neurovascular unit following ischemia-reperfusion injury. Int. J. Biochem. Cell Biol. 2016, 79, 360-369. [CrossRef]

171. Van der Meel, R.; Fens, M.H.; Vader, P.; van Solinge, W.W.; Eniola-Adefeso, O.; Schiffelers, R.M. Extracellular vesicles as drug delivery systems: Lessons from the liposome field. J. Controlled Release 2014, 195, 72-85. [CrossRef]

172. Saari, H.; Lázaro-Ibáñez, E.; Viitala, T.; Vuorimaa-Laukkanen, E.; Siljander, P.; Yliperttula, M. Microvesicle-and exosome-mediated drug delivery enhances the cytotoxicity of Paclitaxel in autologous prostate cancer cells. J. Controlled Release 2015, 220, 727-737. [CrossRef] 
173. Wu, H.; Zhou, J.; Zeng, C.; Wu, D.; Mu, Z.; Chen, B.; Xie, Y.; Ye, Y.; Liu, J. Curcumin increases exosomal TCF21 thus suppressing exosome-induced lung cancer. Oncotarget 2016, 7, 87081. [CrossRef]

174. Vashisht, M.; Rani, P.; Onteru, S.K.; Singh, D. Curcumin encapsulated in milk exosomes resists human digestion and possesses enhanced intestinal permeability in vitro. Appl. Biochem. Biotechnol. 2017, 183, 993-1007. [CrossRef]

175. Yang, T.; Martin, P.; Fogarty, B.; Brown, A.; Schurman, K.; Phipps, R.; Yin, V.P.; Lockman, P.; Bai, S. Exosome delivered anticancer drugs across the blood-brain barrier for brain cancer therapy in Danio rerio. Pharm. Res. 2015, 32, 2003-2014. [CrossRef] [PubMed]

176. Kalani, A.; Chaturvedi, P. Curcumin-primed and curcumin-loaded exosomes: Potential neural therapy. Neural Regen. Res. 2017, 12, 205. [CrossRef] [PubMed]

177. Wang, H.; Sui, H.; Zheng, Y.; Jiang, Y.; Shi, Y.; Liang, J.; Zhao, L. Curcumin-primed exosomes potently ameliorate cognitive function in AD mice by inhibiting hyperphosphorylation of Tau protein through the AKT/GSK-3 $\beta$ pathway. Nanoscale 2019, 11, 7481-7496. [CrossRef] [PubMed]

178. Aqil, F.; Munagala, R.; Jeyabalan, J.; Agrawal, A.K.; Gupta, R. Exosomes for the enhanced tissue bioavailability and efficacy of curcumin. AAPS J. 2017, 19, 1691-1702. [CrossRef] [PubMed]

179. Choi, E.S.; Kang, Y.Y.; Mok, H. Evaluation of the enhanced antioxidant activity of curcumin within exosomes by fluorescence monitoring. Biotechnol. Bioprocess Eng. 2018, 23, 150-157. [CrossRef]

180. Letchford, K.; Liggins, R.; Burt, H. Solubilization of hydrophobic drugs by methoxy poly(ethylene glycol)-block-polycaprolactone diblock copolymer micelles: Theoretical and experimental data and correlations. J. Pharm. Sci. 2008, 97, 1179-1190. [CrossRef]

181. Yoncheva, K.; Kamenova, K.; Perperieva, T.; Hadjimitova, V.; Donchev, P.; Kaloyanov, K.; Konstantinov, S.; Kondeva-Burdina, M.; Tzankova, V.; Petrov, P. Cationic triblock copolymer micelles enhance antioxidant activity, intracellular uptake and cytotoxicity of curcumin. Int. J. Pharm. 2015, 490, 298-307. [CrossRef]

182. Petrov, P.D.; Yoncheva, K.; Gancheva, V.; Konstantinov, S.; Trzebicka, B. Multifunctional block copolymer nanocarriers for co-delivery of silver nanoparticles and curcumin: Synthesis and enhanced efficacy against tumor cells. Eur. Polym. J. 2016, 81, 24-33. [CrossRef]

183. Wittemann, A.; Azzam, T.; Eisenberg, A. Biocompatible polymer vesicles from biamphiphilic triblock copolymers and their interaction with bovine serum albumin. Langmuir 2007, 23, 2224-2230. [CrossRef]

184. Zhang, W.; He, J.; Liu, Z.; Ni, P.; Zhu, X. Biocompatible and pH-responsive triblock copolymer mPEG-b-PCL-b-PDMAEMA: Synthesis, self-assembly, and application. J. Polym. Sci. Part A Polym. Chem. 2010, 48, 1079-1091. [CrossRef]

185. Mazzarino, L.; Otsuka, I.; Halila, S.; Bubniak Ldos, S.; Mazzucco, S.; Santos-Silva, M.C.; Lemos-Senna, E.; Borsali, R. Xyloglucan-block-poly(-caprolactone) copolymer nanoparticles coated with chitosan as biocompatible mucoadhesive drug delivery system. Macromol. Biosci. 2014, 14, 709-719. [CrossRef] [PubMed]

186. Tabatabaei Mirakabad, F.S.; Akbarzadeh, A.; Milani, M.; Zarghami, N.; Taheri-Anganeh, M.; Zeighamian, V.; Badrzadeh, F.; Rahmati-Yamchi, M. A Comparison between the cytotoxic effects of pure curcumin and curcumin-loaded PLGA-PEG nanoparticles on the MCF-7 human breast cancer cell line. Artif. Cells Nanomed. Biotechnol. 2016, 44, 423-430. [CrossRef] [PubMed]

187. Shen, H.; Hu, X.; Szymusiak, M.; Wang, Z.J.; Liu, Y. Orally administered nanocurcumin to attenuate morphine tolerance: Comparison between negatively charged PLGA and partially and fully PEGylated nanoparticles. Mol. Pharm. 2013, 10, 4546-4551. [CrossRef] [PubMed]

188. Song, Z.; Lu, Y.; Zhang, X.; Wang, H.; Han, J.; Dong, C. Novel curcumin-loaded human serum albumin nanoparticles surface functionalized with folate: Characterization and in vitro/vivo evaluation. Drug Des. Dev. Ther. 2016, 10, 2643.

189. Sun, J.; Wang, F.; Sui, Y.; She, Z.; Zhai, W.; Wang, C.; Deng, Y. Effect of particle size on solubility, dissolution rate, and oral bioavailability: Evaluation using coenzyme Q10 as naked nanocrystals. Int. J. Nanomed. 2012, 7, 5733 .

190. Vrána, A.; Andrysek, T. The effect of particle size on bioavailability in cyclosporine preparations based on submicron dispersions. Biomed. Pap.-Palacky Univ. Olomouc 2001, 145, 9-15. [CrossRef]

191. Zhang, L.; Zhang, L. Lipid-polymer hybrid nanoparticles: Synthesis, characterization and applications. Nano. Life 2010, 1, 163-173. [CrossRef] 
192. Bansal, S.S.; Goel, M.; Aqil, F.; Vadhanam, M.V.; Gupta, R.C. Advanced drug delivery systems of curcumin for cancer chemoprevention. Cancer Prev. Res. 2011, 4, 1158-1171. [CrossRef]

193. Kundu, M.; Sadhukhan, P.; Ghosh, N.; Chatterjee, S.; Manna, P.; Das, J.; Sil, P.C. pH-responsive and targeted delivery of curcumin via phenylboronic acid-functionalized $\mathrm{ZnO}$ nanoparticles for breast cancer therapy. J. Adv. Res. 2019, 18, 161-172. [CrossRef]

194. Martin, R.C.; Locatelli, E.; Li, Y.; Zhang, W.; Li, S.; Monaco, I.; Franchini, M.C. Gold nanorods and curcumin-loaded nanomicelles for efficient in vivo photothermal therapy of Barrett's esophagus. Nanomedicine 2015, 10, 1723-1733. [CrossRef]

195. Nosrati, H.; Charmi, J.; Salehiabar, M.; Abhari, F.; Danafar, H. Tumor targeted albumin coated bismuth sulfide nanoparticles (Bi2S3) as radiosensitizers and carriers of curcumin for enhanced chemoradiation therapy. ACS Biomater. Sci. Eng. 2019, 5, 4416-4424. [CrossRef]

196. Huang, Y.; Hu, L.; Huang, S.; Xu, W.; Wan, J.; Wang, D.; Zheng, G.; Xia, Z. Curcumin-loaded galactosylated BSA nanoparticles as targeted drug delivery carriers inhibit hepatocellular carcinoma cell proliferation and migration. Int. J. Nanomed. 2018, 13, 8309. [CrossRef] [PubMed]

197. Song, W.; Su, X.; Gregory, D.; Li, W.; Cai, Z.; Zhao, X. Magnetic alginate/chitosan nanoparticles for targeted delivery of curcumin into human breast cancer cells. Nanomaterials 2018, 8, 907. [CrossRef] [PubMed]

198. Saikia, C.; Das, M.K.; Ramteke, A.; Maji, T.K. Evaluation of folic acid tagged aminated starch/ZnO coated iron oxide nanoparticles as targeted curcumin delivery system. Carbohydr. Polym. 2017, 157, 391-399. [CrossRef] [PubMed]

199. Manju, S.; Sreenivasan, K. Conjugation of curcumin onto hyaluronic acid enhances its aqueous solubility and stability. J. Colloid Int. Sci. 2011, 359, 318-325. [CrossRef] [PubMed]

200. Thulasidasan, A.K.T.; Retnakumari, A.P.; Shankar, M.; Vijayakurup, V.; Anwar, S.; Thankachan, S.; Pillai, K.S.; Pillai, J.J.; Nandan, C.D.; Alex, V.V. Folic acid conjugation improves the bioavailability and chemosensitizing efficacy of curcumin-encapsulated PLGA-PEG nanoparticles towards paclitaxel chemotherapy. Oncotarget 2017, 8, 107374. [CrossRef]

201. Nam, N.H.; Doan, D.H.; Nhung, H.T.M.; Quang, B.T.; Nam, P.H.; Thong, P.Q.; Phuc, N.X.; Thu, H.P. Folate attached, curcumin loaded Fe3O4 nanoparticles: A novel multifunctional drug delivery system for cancer treatment. Mater. Chem. Phys. 2016, 172, 98-104.

202. Li, L.; Xiang, D.; Shigdar, S.; Yang, W.; Li, Q.; Lin, J.; Liu, K.; Duan, W. Epithelial cell adhesion molecule aptamer functionalized PLGA-lecithin-curcumin-PEG nanoparticles for targeted drug delivery to human colorectal adenocarcinoma cells. Int. J. Nanomed. 2014, 9, 1083-1096. 